\title{
PETROGRAPHIC CHARACTERISTICS OF SELECTED TERTIARY COALS FROM WESTERN INDONESIA ACCORDING TO THEIR GEOLOGICAL ASPECTS
}

\author{
KARAKTERISTIK PETROGRAFIS BATUBARA TERSIER \\ INDONESIA BAGIAN BARAT BERDASARKAN ASPEK-ASPEK \\ GEOLOGISNYA
}

\author{
BINARKO SANTOSO \\ Research \& Development Centre for Mineral and Coal Technology \\ Jalan Jenderal Sudirman 623 Bandung 40211 \\ Ph. (+6222) 6030483, Fax. (+6222) 6003373 \\ e-mail: binarkos@tekmira.esdm.go.id
}

\begin{abstract}
Selected Tertiary coals from the western part of Indonesia (Sumatera, Kalimantan and Java) indicate similarities and differences in type and rank characteristics. These coals reflect their geological setting, particularly for intrusive and stratigraphic aspects. Type and rank of the coals were assessed by petrographic examination. The coals are mainly dominated by vitrinite, common liptinite and rare inertinite and mineral matter. Vitrinite macerals are dominated detrovitrinite and telovitrinite. Resinite, cutinite and suberinite are the dominant liptinite macerals in the coals. Inertinite macerals in the coals consist of semifusinite, sclerotinite and inertodetrinite. The type differences largely reflect climatic influence and differences in peat conditions. In spite of short geological history, the coals exhibit variable vitrinite reflectances. The high vitrinite reflectance of the coals is a result of higher regional coalification levels in the basins associated with greater cover and effects of igneous intrusions.
\end{abstract}

Keywords: coal, maceral, type, rank, western Indonesia.

\begin{abstract}
ABSTRAK
Percontoh-percontoh batubara yang terdapat di Indonesia bagian barat (Sumatera, Kalimantan dan Jawa) mengindikasikan kesamaan dan perbedaan dalam karakteristik jenis dan peringkatnya. Karakteristik petrografis batubara ini mencerminkan kondisi tataan kondisi geologisnya, terutama aspek intrusif dan startigrafisnya. Batubara Indonesia ini didominasi oleh vitrinit, liptinit, sedikit inertinit dan mineral. Maseral vitrinit didominasi oleh detrovitrinit dan telovitrinit. Resinit, kutinit dan suberinit merupakan maseral yang dominan di kelompok maseral liptinit. Maseral inertinit dalam batubara ini terdiri atas semifusinit, sklerotinit dan inertodetrinit. Perbedaan jenis batubara ini diakibatkan oleh pengaruh iklim dan perbedaan kondisi pembentukan gambut. Meskipun memperlihatkan sejarah geologis yang pendek, batubara ini menunjukkan keberagaman reflektan vitrinitnya. Reflektan batubara yang tinggi merupakan hasil tingkat pembatubaraan regional yang lebih tinggi dalam cekungan yang berasosiasi dengan lapisan batuan penutupnya dan efek intrusi batuan beku.
\end{abstract}

Kata kunci: batubara, maseral, jenis, peringkat, Indonesia bagian barat

\section{INTRODUCTION}

Most of the Tertiary (Palaeogene and Neogene) Indonesian coals dominated by low-rank and vitrinite-rich coals (Santoso and
Daulay, 2007, 2008; Daulay and Santoso, 2008; Belkin et al., 2009; Santoso, 2010, 2011, 2015; Widodo et al., 2010; Susilawati et al., 2015; Friederich, Moore and Flores, 2016). Geologically, Tertiary coal deposits in 
Sumatera and Java are intruded by igneous rocks, namely andesite and diorite, respectively (Darman, 2000; Daulay and Santoso, 2008; Daulay et al., 2010; Santoso, 2010; Hartono, 2012). It is predicted that probably the coals have various ranks and maceral composition. In addition, the age factor, namely Palaeogene and Neogene, can explain different coal rank due to cover or stratigraphic aspect. In this paper, a serious attempt was made to analyze these phenomena. Moreover, this paper can contribute Indonesia's coal petrographic data, particularly for assessing the utilization potential of the coals.

This study is aimed at obtaining aspects as follows:

- to determine type and rank characteristics of a representative suite of selected Tertiary western Indonesian (Sumatera, Kalimantan and Java) coals;

- to establish the patterns of variation of type and rank;

- to examine the relation of type and rank to the geologic setting, particularly intrusive and stratigraphic aspects.

To achieve these aims, analyses of maceral and mineral matter of major coalfields of western Indonesia, including Ombilin, Bukit Asam, East and South Kalimantan and western Java, were carried out in this study.

\section{METHODOLOGY}

The samples studied (10 samples from Ombilin, 116 samples from Bukit Asam, 40 samples from East and South Kalimantan, and 28 samples from Java coalfields) were obtained from Indonesia's Tertiary coalfields (Figure 1). Sampling was based on the procedure of the Australian Standard (Australian Standard, 1998, 2000).

All samples were examined in both reflected white light and reflected ultraviolet-violet light excitation. Maceral analyses were determined in oil immersion by reflected plane polarized light at a magnification of $x 500$. Polarized light was essential for examination of thermally altered samples. The liptinite (exinite) group of macerals was studied using ultraviolet-violet light excitation at a magnification of $\times 500$. Fluorescence examination was conducted using a Leitz Orthoplan microscope. The orthoplan microscope fitted with a Leitz Vario-Orthomat camera that incorporates a 5 to $12.5 x$ zoom was used for all photography.

Reflectance measurements were carried out using a Leitz Ortholux I microscope fitted with a Leitz MPV 1 microphotometer. The microphotometer was calibrated against synthetic garnet standards of $0.917 \%$ and $1.726 \%$ reflectance and s synthetic spinel of $0.413 \%$ reflectance. The galvanometer was set to provide a reading of one-half the reflectances multiplied by 100 .

Normal point count techniques were used for maceral analyses. Approximately 500 points were counted for each maceral analysis. After completion of the analysis of each individual maceral, maceral group or mineral was expressed as a percentage of the points recorded. Each point could be examined in reflected white light and fluorescence mode.

The normal practice of reflectance measurement was to rotate the stage of the microscope to obtain a maximum reading and then rotate the stage about $180^{\circ}$ for the second maximum reading. The acceptable maximum pairs were averaged to give the mean maximum vitrinite reflectance in oil immersion (referred to herein as Rvmax). Reflectance measurements were made on vitrinite because it undergoes consistently changes with rank. It shows some inherent variability in reflectance according to type. It is the most abundant maceral in most coals and occurs as relatively large particles and accordingly enabling easy measurements.

\section{GEOLOGICAL SETTING}

It is usually acknowledged that the physiographic setting of the Indonesian archipelago is dominated by continental shelf regions, namely Sunda and Sahul Shelf. The Sunda Shelf area lies in the west and the Sahul Shelf in the east, separated by a geologically complex region of deep sea basins and island arcs. Both shelf areas comprising intensely deformed pre-Tertiary sedimentary and crystalline igneous and metamorphic rocks have been tectonically stable since Tertiary time. The islands of Sumatera, Kalimantan and Java are physiographically attached to the Sunda Shelf of the Asian continent (Figure 2; Darman, 2000). 


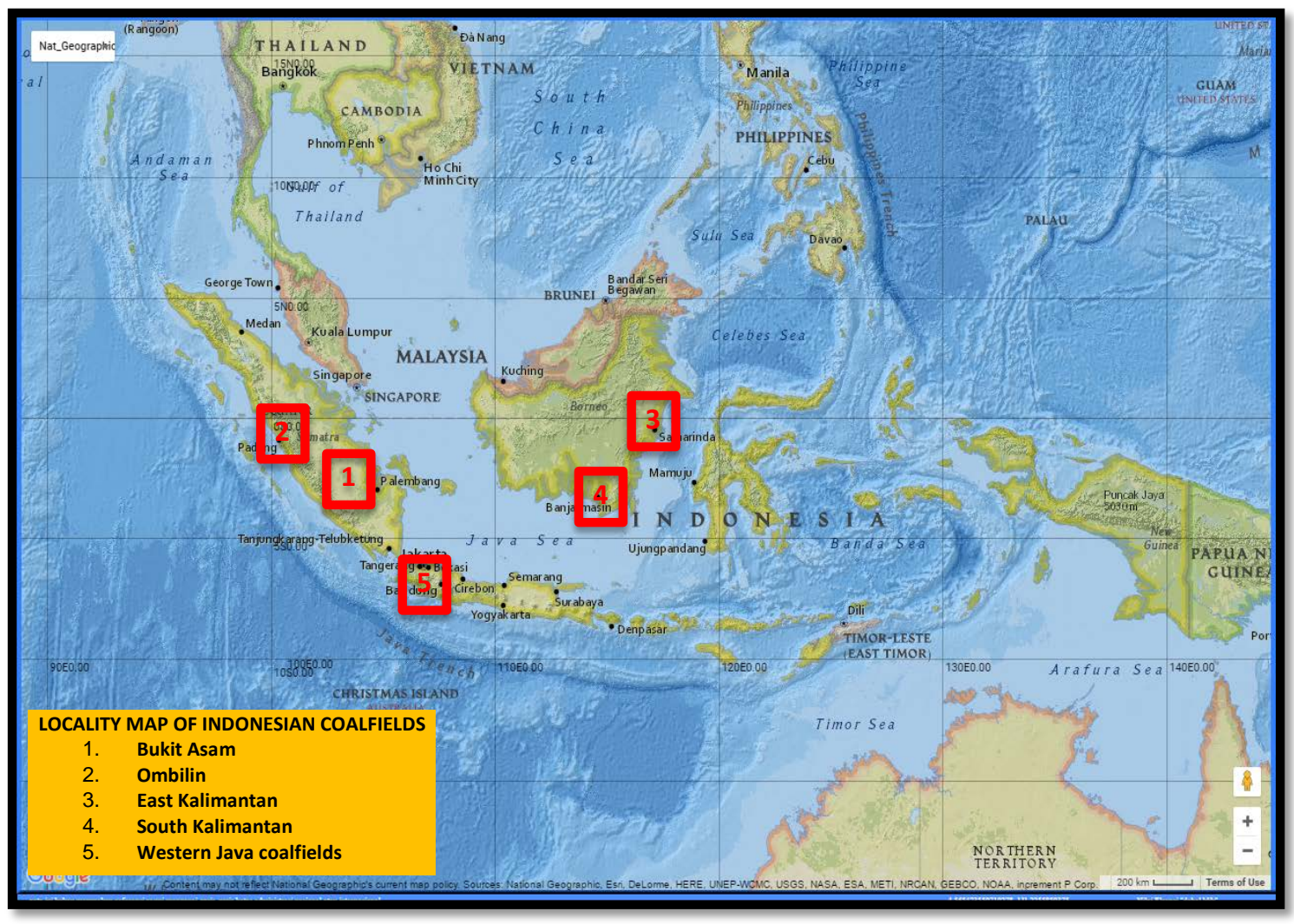

Figure 1. Locality map of Indonesian coalfields

(1. Bukit Asam, 2. Ombilin, 3. East Kalimantan, 4. South Kalimantan, and 5. Western Java coalfields)

Global tectonics concepts have been used by some authors (Koesoemadinata, 1978; Katili, 1980; Darman, 2000), to explain the structural and tectonic development of Indonesian regions. The Indonesian islands are considered as the result of interactions between three crustal blocks, namely: the Indian Ocean-Australian, the Pacific and the Eurasian plates. Indonesia is tectonically divided into western Indonesia (Sumatera, Java, Kalimantan and western Sulawesi) and eastern Indonesia (eastern Sulawesi, Moluccas and western Papua). One of the major differences between western and eastern Indonesia is the presence throughout eastern Indonesia of Permian and Mesozoic strata. This is not the case in western Indonesia.

\section{A. Sumatera}

The structural development of Sumatera is generally attributed to the interaction of two major crustal plates, namely: the Southeast Asian plate (Sunda Shelf) and the Indian Ocean plate (Darman, 2000). This interaction caused strong deformation of the Mesozoic and Palaeozoic complexes of the Barisan Range that is located on the western side of Sumatera. East of the range, along the western edge of the Sunda Shelf, a series of Tertiary basins were developed, one of these being the South Sumatera Basin. The intermontane Ombilin Basin is developed in the western part of the island.

In association with coal deposition, the most important sedimentary basins are Palaeogene intermontane basins, Neogene back-deep basins and Neogene deltaic basins (Koesoemadinata, 1978; Amijaya and Littke, 2006; Susilawati and Ward, 2006; Santoso and Daulay, 2007; Sosrowidjojo and Saghafi, 2009). Coal seams deposited within the Palaeogene intermontane basins are interbedded with lacustrine, fluviatile, alluvial plain and near shore deposits (Santoso and Daulay, 2007; Daulay and Santoso, 2008). The coal seams tend to be limited in lateral extent, but numerous seams are present within the coal measure sequence. 


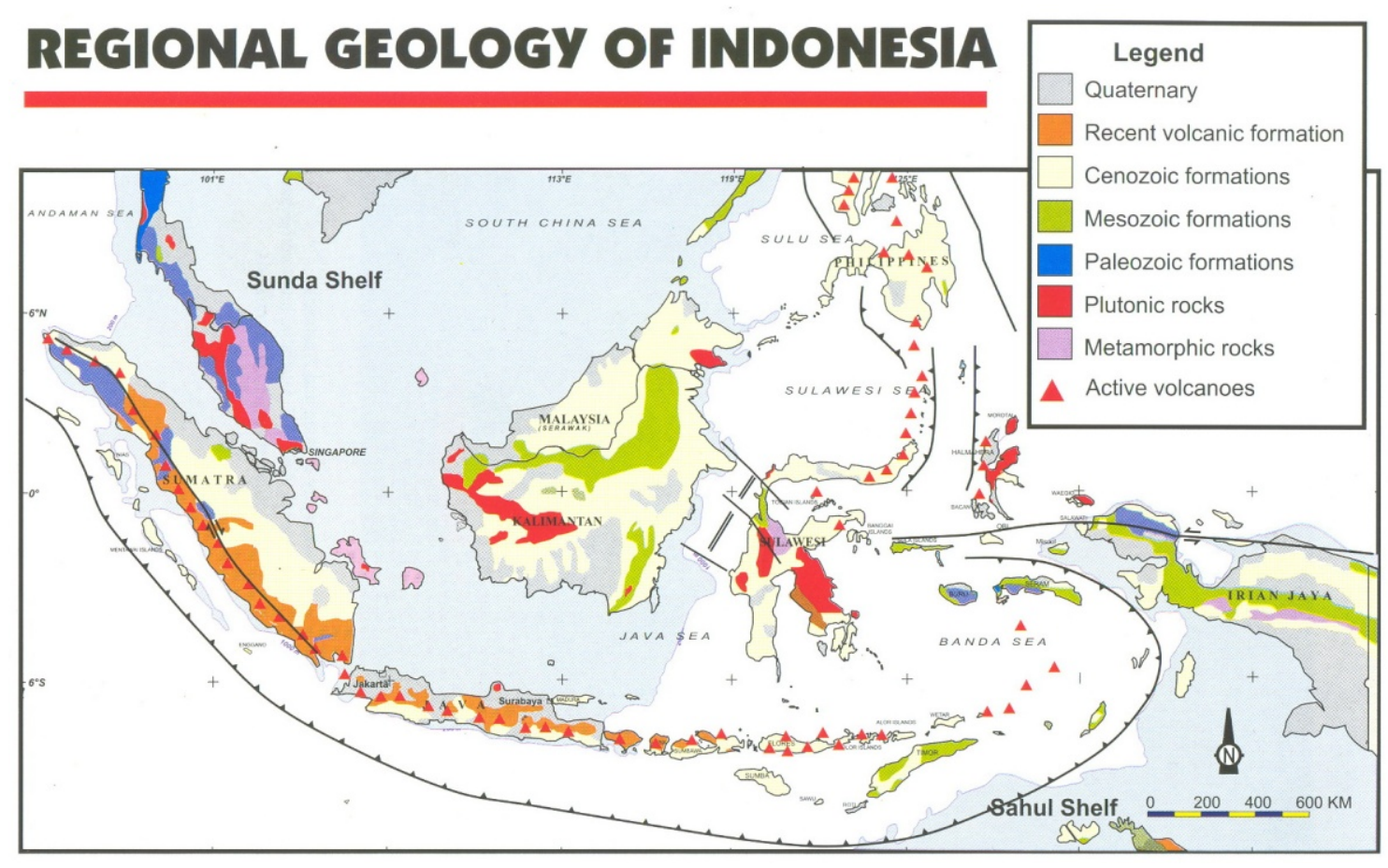

Figure 2. Geology of Indonesia (Darman and Sidi, 2000)

A Neogene basinal back-deep basin developed where marine clastic sedimentation occurred above the Palaeogene sediments, forming some local basal unconformities (Daulay and Santoso, 2008). This marine sedimentation cycle terminated with a regressive sequence where vast swampy areas developed to result in extensive coal deposits like in South Sumatera basinal area. The coal deposition occurred in a paralic to a limnic and brackish environment.

\section{Palaeogene/Ombilin Coalfield}

The Ombilin Coalfield is located on the northwest margin of the Eocene Ombilin Basin in West Sumatera Province. The basin is structurally controlled by wrench faulting that is related to the Great Sumatera Fault Zone (Santoso and Daulay, 2007; Daulay and Santoso, 2008; Santoso, 2015).

The Palaeogene cycle of sedimentation in the Ombilin Basin represents the initial terrestrial phase of the Tertiary sequence
(Santoso and Daulay, 2007; Daulay and Santoso, 2008). The Palaeogene sequence was deposited in an intermontane basin that developed at the beginning of the Tertiary when the pre-Tertiary landmass was blockfaulted into grabens. The graben-like basin was filled from all sides by alluvial fans, whilst several lakes existed in the central basin. The basin became an alluvial valley with meandering rivers followed by a braided river before it was folded and uplifted in the Early Miocene. A number of anticlines and synclines are present in the basin.

The coal measures occur in two stratigraphic units, which are the Sawahlunto and Sawahtambang Formations (Daulay dan Santoso, 2008; Santoso dan Daulay, 2007 Figure 3). Three coal seams occur in the Sawahlunto Formation. A detailed stratigraphic sequence of the coal measures is provided in Figure 4. Coal seams of the Sawahtambang Formation are exposed in the southeastern part of the basin. The coal seams are very thin (15-18 cm thick within the coal measure sequence.). 
Petrographic Characteristics of Selected Tertiary Coals from Western ... Binarko Santoso

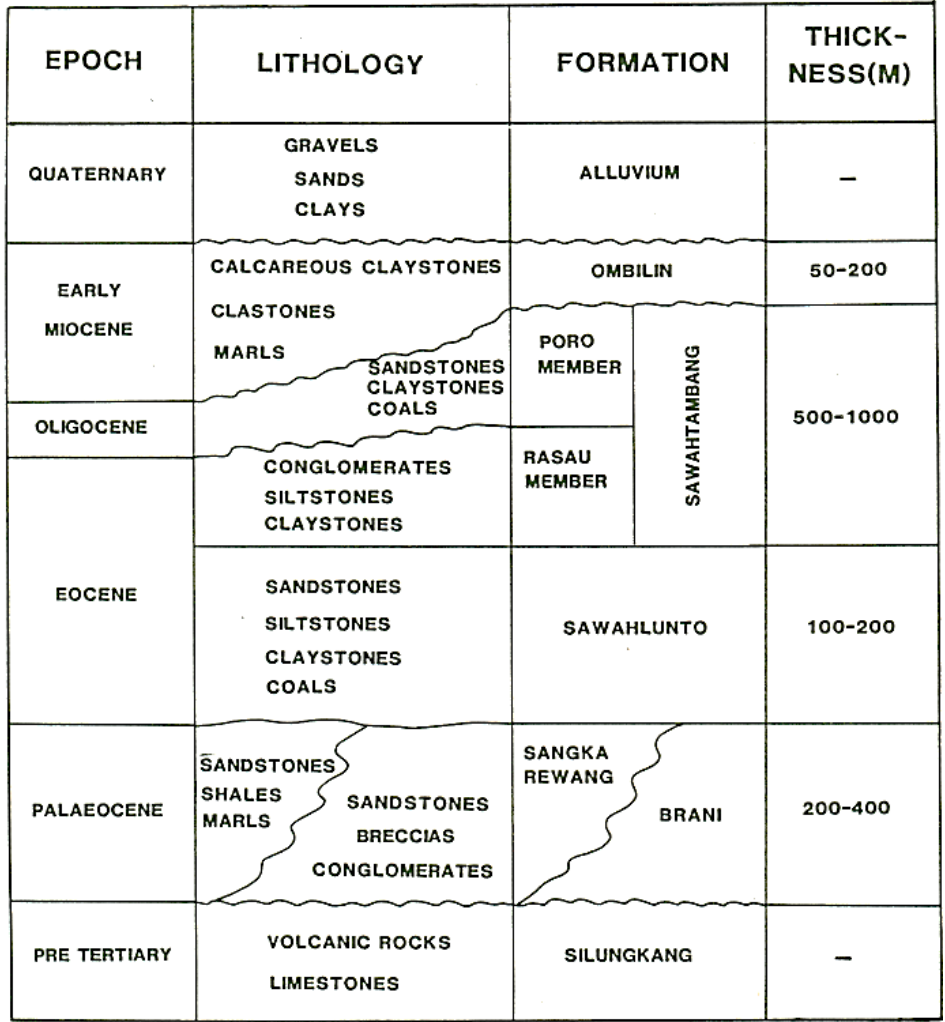

Figure 3. Stratigraphy of the Ombilin Basin (Daulay and Santoso, 2008)

\begin{tabular}{|c|c|c|c|c|}
\hline 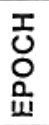 & 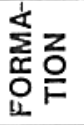 & 站 & $\begin{array}{l}\text { 웡 } \\
\text { É }\end{array}$ & DESCRIPTION \\
\hline $\begin{array}{l}\text { 㟛 } \\
\text { ü } \\
\text { 。 }\end{array}$ & 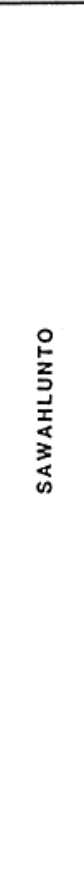 & 吉 & 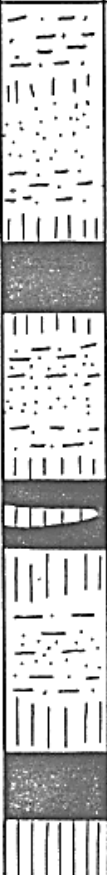 & $\begin{array}{l}\text { CLAYSTONE, SILTSTONE AND SANDSTONE } \\
\text { A1 SEAM WITH SMALL CLAY PARTINGS } \\
\text { (1 TO } 3.5 \text { METRES) } \\
\text { CLAYSTONE, SILTSTONE AND SANDSTONE } \\
\text { (7 TO } 10 \text { METRES) } \\
\text { B1 SEAM ( } 1 \text { TO } 2 \text { METRES) } \\
\text { CLAYSTONE, SILTSTONE (2 TO } 3 \text { METRES) } \\
\text { B2 SEAM (1.5 TO } 2 \text { METRES) } \\
\text { CLAYSTONE, SILTSTONE AND SANOSTONE } \\
\text { (15 TO } 20 \text { METRES) } \\
\text { C COAL, SMALL CLAY PARTINGS } \\
\text { (3 TO } 5 \text { METRES) } \\
\text { CLAYSTONE AND SILTSTONE }\end{array}$ \\
\hline
\end{tabular}

Figure 4. Stratigraphic sequence of the Ombilin coal measures (Daulay and Santoso, 2008) 


\section{Neogene/Bukit Asam Coalfield}

Tertiary sediments of the Bukit Asam area were deposited in the South Sumatera Basin. The regional stratigraphy of the South
Sumatera coal province is described by Amijaya dan Littke (2006), Susilawati dan Ward (2006) and Sosrowidjojo dan Saghafi (2009) as illustrated in Figure 5.

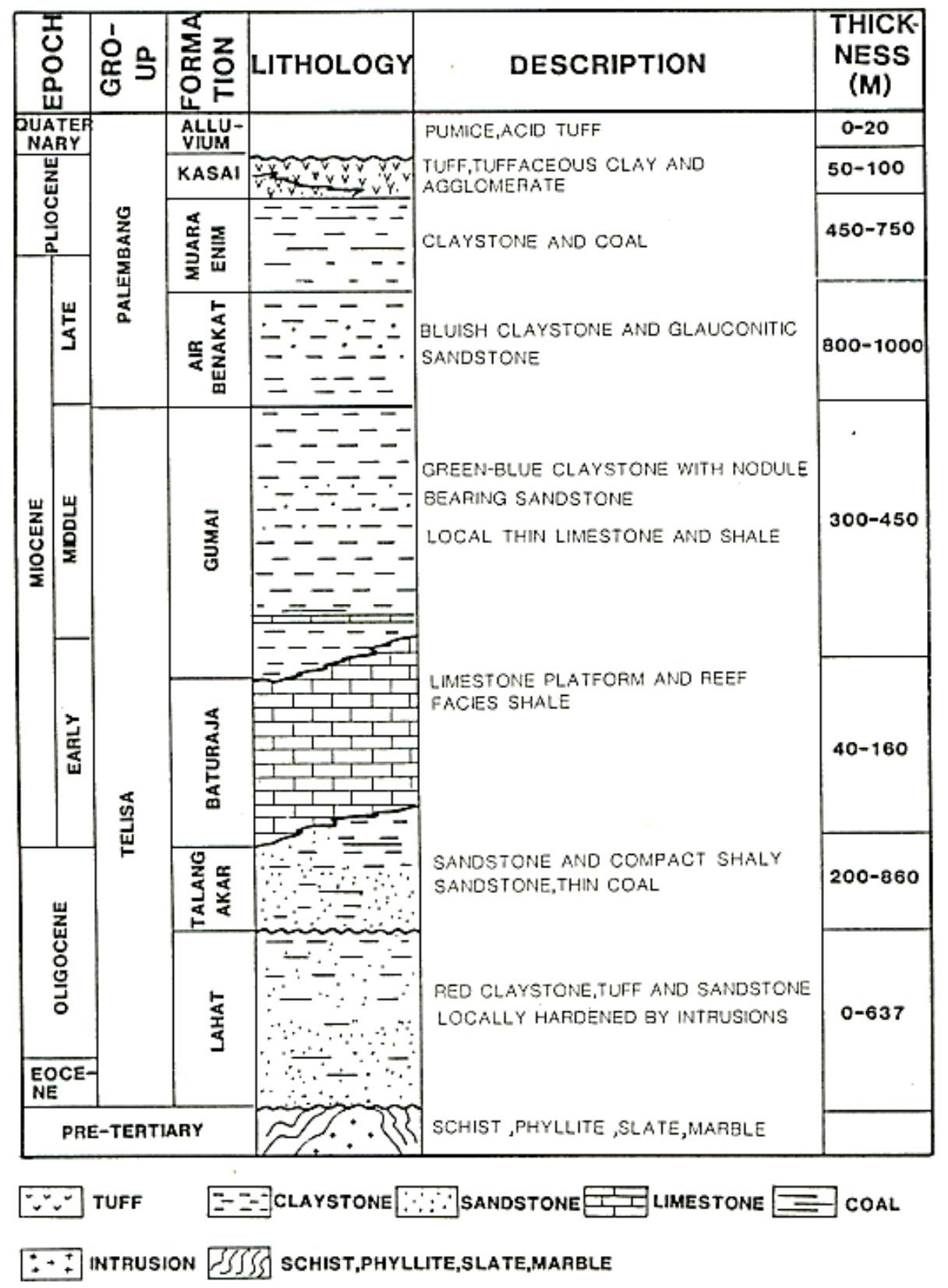

Figure 5. Stratigraphy of the South Sumatera Basin (Amijaya and Littke, 2006; Susilawati and Ward, 2006; Sosrowidjojo and Saghafi, 2009) 


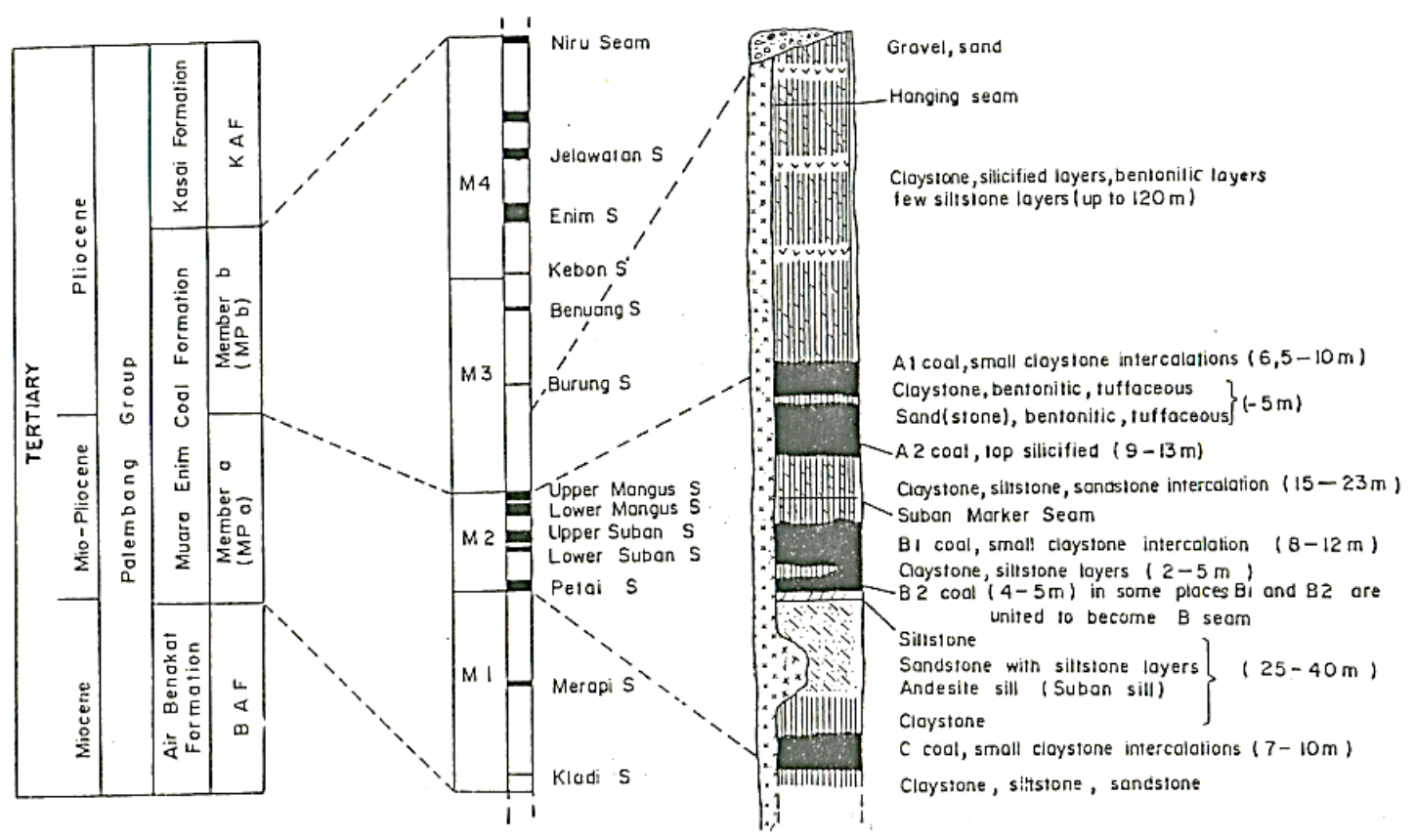

Figure 6. Stratigraphy of the Bukit Asam area (Amijaya and Littke, 2006; Susilawati and Ward, 2006; Sosrowidjojo and Saghafi, 2009)

The workable coal measures of the South Sumatera Basin are developed in Muara Enim Formation as shown in Figure 6 (Amijaya and Littke, 2006; Susilawati and Ward, 2006; Sosrowidjojo and Saghafi, 2009). The thickness of the Late MiocenePliocene Muara Enim Formation is $450-750$ meters. These authors believed that six major coal seams and several thin coal seams are present in the Bukit Asam area. The Bukit Asam coals are autochthonous in origin. Seat earth (claystone) occur at the base of the seams.

\section{B. Kalimantan}

In eastern Kalimantan, marginal basins developed as the result of Miocene rifting of Sulawesi from Kalimantan (Darman, 2000). Two large deltas prograded from the Sunda Landmass in the west over the oceanic crust of the Makassar Strait.

An overall westward marine transgression prevailed in the northwest Kutai Basin until Late Oligocene when orogenic activity and the initial emergence of the Kuching High reversed the direction of shoreline migration. In the central Kutai Basin, marine transgression was dominant through the
Early-Middle Miocene. Koesoemadinata (1978) suggested that the deposition of coal occurred in a deltaic environment.

During Late Miocene, uplift of the Meratus Mountain divided the southern Kutai Basin into the Barito and Pasir Basins. Stratigraphic sequence of the Kutai Basin proposed by Santoso dan Daulay (2005a, 2005b) is shown in Figure 7.

\section{Palaeogene coals}

Palaeogene coal measures are present in the Pasir (East Kalimantan; Santoso, 2011) and Barito (South Kalimantan; Santoso dan Daulay, 2005a) Basins. Three coal seams resting on pre-Tertiary ultramafic rocks and mudstone or conglomerate are recognized in the Pasir Basin. Tanjung Formation (Middle Eocene) that is the oldest Tertiary sedimentary section in the Barito Basin (Figure 8) consists of sandstones, shales, conglomerates and coal seams. Santoso dan Daulay (2005a) reported that the Tanjung Formation was laid down in fresh to brackish water and deltaic environments, with increasing marine influence in the younger sediments. Five coal seams are present. 
INDONESIAN MINING JOURNAL Vol. 20, No. 1, April $2017: 1$ - 30

\begin{tabular}{|c|c|c|c|c|}
\hline \multicolumn{2}{|c|}{ EPOCH } & FORMATION & LITHOLOGY & $\begin{array}{c}\text { THICKNESS } \\
(\mathrm{m})\end{array}$ \\
\hline Quaternary & Pleistocene & Alluvium & $\begin{array}{c}\text { Sands } \\
\text { Silts } \\
\text { Clays }\end{array}$ & - \\
\hline \multirow{7}{*}{ Tertiary } & Pliocene & $\begin{array}{c}\text { Kampung } \\
\text { Baru }\end{array}$ & $\begin{array}{c}\text { Sandstones } \\
\text { Siltstones } \\
\text { Mudstones } \\
\text { Coals }\end{array}$ & 900 \\
\cline { 2 - 5 } & $\begin{array}{c}\text { Middle to Late } \\
\text { Miocene }\end{array}$ & Balikpapan & $\begin{array}{c}\text { Sandstones } \\
\text { Coals } \\
\text { Limestones }\end{array}$ & 3,000 \\
\cline { 2 - 5 } & Early Miocene & Pulubalang & $\begin{array}{c}\text { Mudstones } \\
\text { Limestones } \\
\text { Sandstones }\end{array}$ & 2,750 \\
\cline { 2 - 5 } & Oligocene & Pamaluan & Sandstones & - \\
\hline
\end{tabular}

Figure 7. Tertiary stratigraphy of Kutai Basin (Santoso and Daulay, 2005b, 2005c)

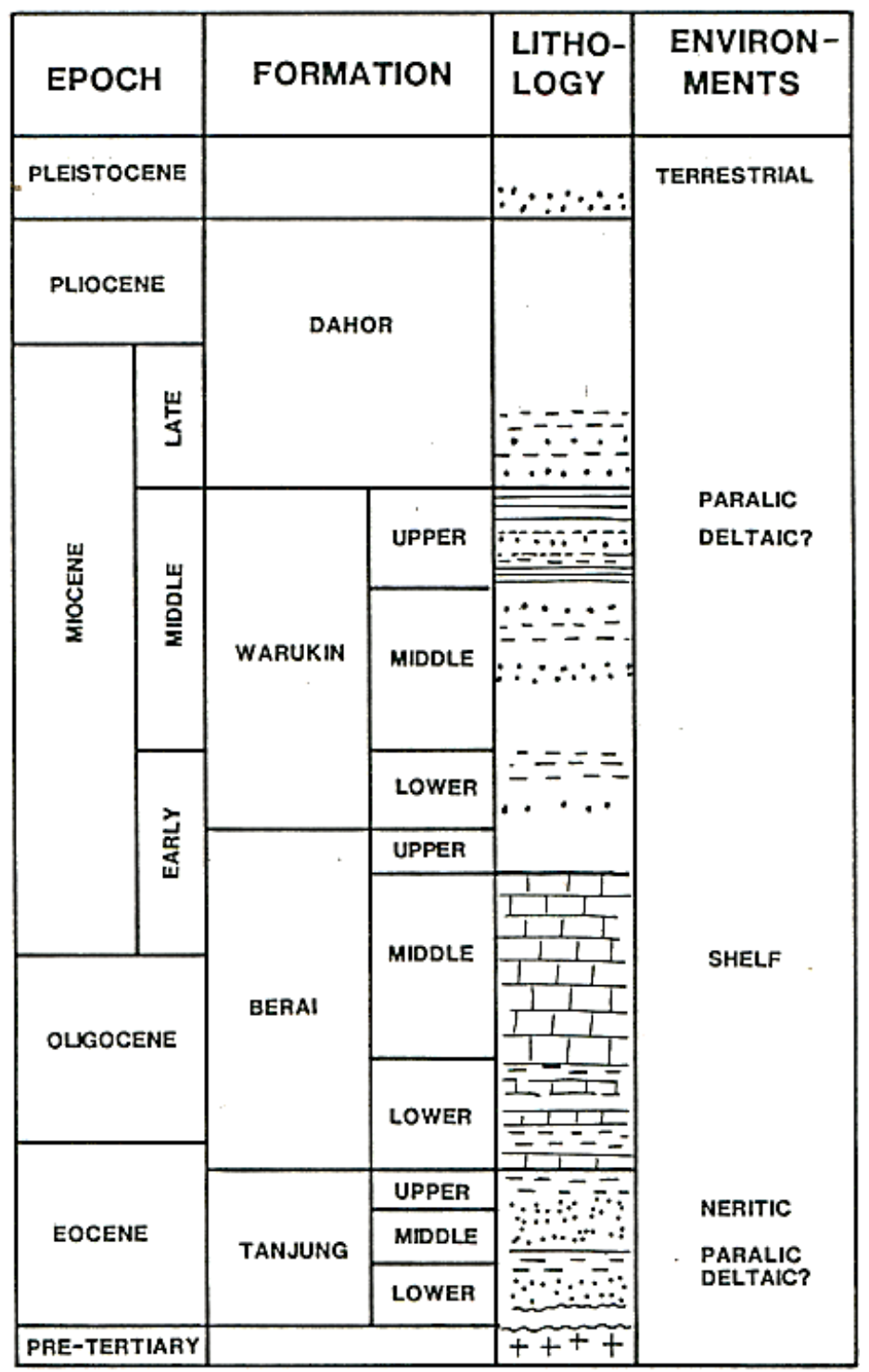

Figure 8. Stratigraphic column of Barito Basin (Santoso and Daulay, 2005c) 


\section{Neogene coals}

Neogene coal measures are present in the Kutai and Barito Basins (Santoso and Daulay, 2005c; Daulay, Santoso and Ningrum, 2015). The principal coal-bearing strata in the Kutai Basin are the Early Miocene Pamaluan and Pulubalang Formations and the Miocene to Pliocene Balikpapan and Kampungbaru Formations. In the west and south of Samarinda, the Pulubalang Formation comprises a series of limestone lenses, calcareous mudstone and thin sandstones that are essentially marine. The overlying Lower Balikpapan Formation consists of a series of coal measures that are indicative of deltaic environment (Santoso and Daulay, 2005c; Moore, Bowe and Nas, 2014). The Upper Balikpapan Formation contains a greater proportion of sandstone, the deltaic sequence becoming more strongly influenced by fluvial processes. In the Barito Basin, thick beds (up to 3 meters) of Neogene coals are widespread in the paralic Warukin and Dahor Formations.

\section{Java}

Palaeogene and Neogene coals are not well developed in Java (Koesoemadinata, 1978; Santoso and Daulay, 2005a, 2007; Santoso, 2010). Terrestrial pre-transgressive sedimentation occurred in Banten only (Bayah and Cimandiri areas), and resulted in coal deposition; whereas in Central and East Java, sedimentation was associated with a marine transgression that occurred over the pre-Tertiary basement. The Palaeogene coals are included in a monotonous series of quartz sandstones (partly conglomeratic) and claystones of Bayah Formation (Koesoemadinata, 1978; Santoso, 2010; Santoso dan Daulay, 2007, 2005c; Figure 9). The Eocene sediments are strongly folded particularly in the Cimandiri area. In this area, the coal seams reach dips up to $90^{\circ}$. Some small andesitic intrusions occur in Cimandiri. The coal seams seldom exceed a thickness of one meter, and exceptionally are two meters in thickness.

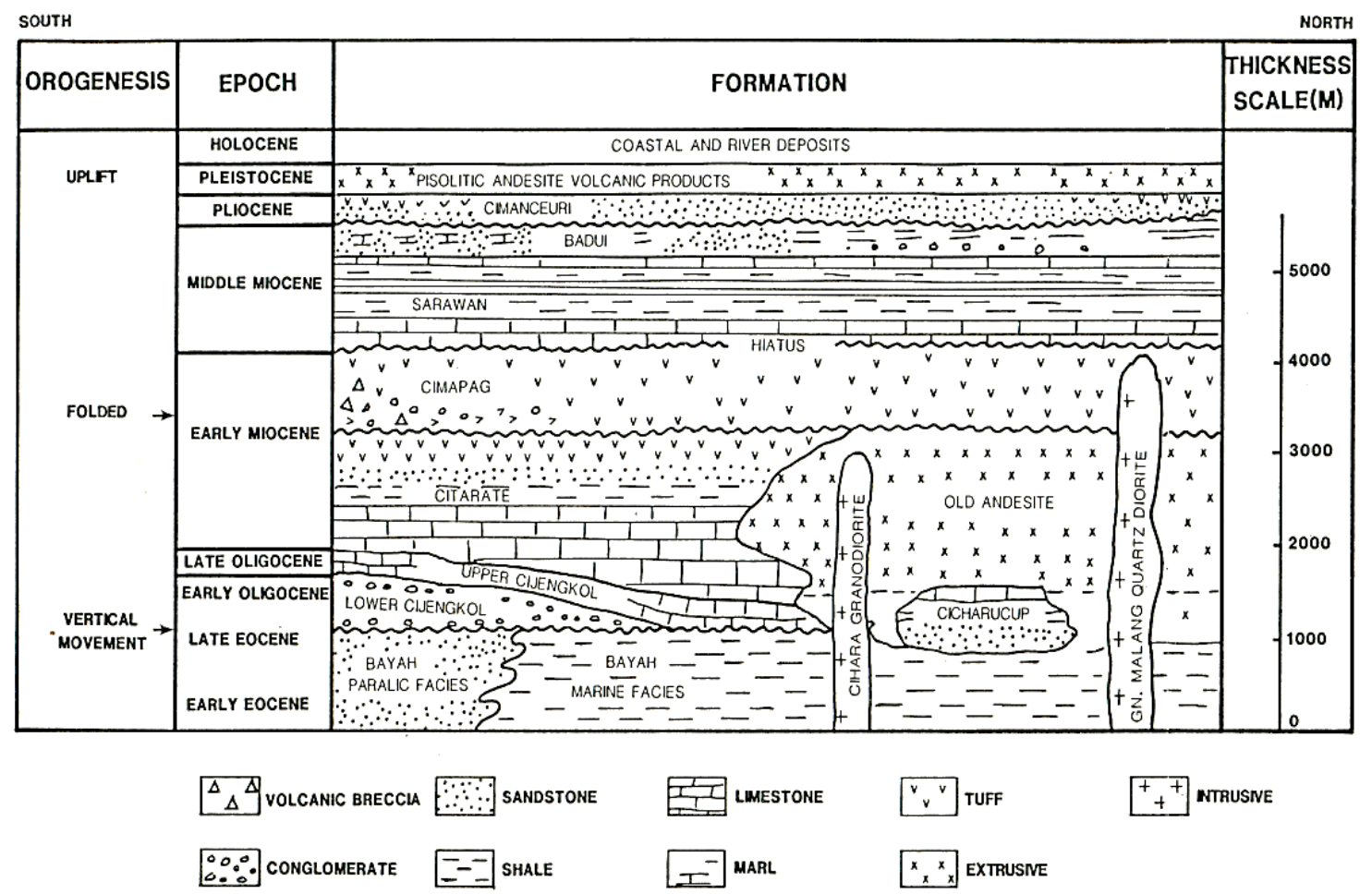

Figure 9. Stratigraphic diagram of the Banten area (Koesoemadinata, 1978; Santoso and Daulay, 2005a, 2007; Santoso, 2010). 
Some authors like Koesoemadinata (1978), Santoso dan Daulay (2005c) and Santoso (2010) reported that up to nine coal seams occur in some sections. In some localities, the coals are highly lenticular. No reliable index-strata are available for correlation of the various coal measures. The Neogene coal seams take place in an upper Miocene tuffaceous series that consists of sandstones, mudstones, conglomerates, pumiceous and quartz-bearing tuffs and tuff-breccias.

\section{RESULTS AND DISCUSSION}

\section{Results}

\section{A. Sumatera}

The Sumatran Tertiary coals consist mainly of vitrinite and liptinite macerals. Vitrinite consists essentially of the interbedded detrovitrinite matrix and telovitrinite bands. Gelovitrinite, including corpovitrinite and porigelinite, occurs throughout the coals. Liptinite consists of resinite, cutinite, suberinite, sporinite, liptodetrinite, fluorinite and exsudatinite. Alginite is present in the Ombilin coals. Inertinite is rarely present in Sumatran coals. Approximately $50 \%$ of the inertinite is semifusinite and the rest is sclerotinite, inertodetrinite and rare fusinite.

The Sumatran coals have a low mineral matter content that is less than $5 \%$ including mainly pyrite and clay. Pyrite occurs as fine grains throughout the coals. Clay occurs mostly as fine-grained inclusions dispersed throughout the coals. Clay infills plant cell cavities, usually in vitrinite.

Reflectance studies of Sumatran Tertiary coals reveal that the coals range from brown coals through to anthracite stages. In normal, rank increases with the depth of burial and geothermal gradient in the Sumatran coal-bearing basins. However, some coal seams in Ombilin and Bukit Asam Coalfields exhibit abnormally high vitrinite reflectances due to the proximity of andesite intrusions. The Ombilin coals not affected by contact alteration are high volatile bituminous rank; whereas thermally altered coals are anthracite. The Bukit Asam coals not affected by contact alteration range from brown coal to subbituminous coal rank. The Bukit Asam thermally altered coals range from high volatile bituminous through to semi-anthracite and anthracite. The higher rank of the Ombilin coals compared with the Bukit Asam coals is due to their different thermal history with higher temperatures acting over longer periods at Ombilin.

\section{Coal type \\ Palaeogene/Ombilin}

The Palaeogene Ombilin coals are composed largely of vitrinite and liptinite with inertinite being rare. Thermally affected coals commonly contain high vitrinite and rare inertinite, but no recognizable liptinite.

The vitrinite content in Ombilin coals has a range between $80 \%$ and $96 \%$ with an average of $90 \%$ (Table 1). Detrovitrinite forms a matrix for isolated thin bands of telovitrinite and for liptinite. The detrovitrinite matrix comprises more than $50 \%$ of the total vitrinite in most of the coals. Gelovitrinite (mainly corpovitrinite and porigelinite) occurs throughout the coals that are commonly associated with suberinite.

The liptinite content ranges from $2 \%$ to $14 \%$ with an average of $6 \%$. Cutinite (Figures 10a and $10 \mathrm{~b})$, resinite and liptodetrinite are the dominant liptinite macerals. However, suberinite and sporinite are dominant in some occurrences. Fluorinite, exsudatinite and alginite occur in few coals and are rare.

Inertinite is a minor constituent in the Ombilin coals. The inertinite content varies between a trace and $6 \%$ with an average of $2 \%$. Sclerotinite is the dominant inertinite group maceral and consists of sclerotia. Semifusinite occurs as thin layers and rarely as isolated lenses in a detrovitrinite matrix. Inertodetrinite constitutes $1 \%$ of the coals. It occurs angular and irregular forms disseminated throughout the coals.

Mineral matter includes mainly clay and pyrite and is rare in the Ombilin coals. It usually constitutes a trace to $1 \%$, although some coals contain more than $3 \%$. Most of the mineral matter occurs as pods disseminated throughout the coals. Framboidal pyrite is common in the thinner seam.

In summary, the liptinite and inertinite contents of the Ombilin coals are systematically related to the vitrinite content. 
The liptinite and inertinite contents decrease with increase in the vitrinite content. The liptinite content is not related to the inertinite content.

\section{Neogene/Bukit Asam}

Vitrinite, liptinite and inertinite occur in the Bukit Asam coals. Each coal seam has a similarity of maceral composition. Due to the thermal effects of an intrusion, the coals are divided into unaffected and heat affected coals. Both unaffected and affected coals have different maceral compositions.
Vitrinite content of the Neogene Bukit Asam coals unaffected by contact alteration varies from $76 \%$ to $96 \%$ with an average of $87 \%$ (Appendix 1). It typically occurs as a matrix of detrovitrinite, thin layers or small lenses of telovitrinite associated with liptinite and inertinite (Figures $11 \mathrm{a}$ and $11 \mathrm{~b}$ ). Some of the telovitrinite cell lumens are infilled with fluorinite or resinite. In some cases, they are filled by clay minerals. Gelovitrinite is scattered throughout the coals.

Table 1. Maceral composition of the Palaeogene Ombilin coals

\begin{tabular}{|c|c|c|c|c|c|c|c|c|c|c|c|c|c|c|}
\hline \multirow[t]{2}{*}{ LOCATION } & \multirow{2}{*}{ SEAM } & \multicolumn{4}{|c|}{ VITRINITE (\%) } & \multicolumn{4}{|c|}{ INERTINITE (\%) } & \multicolumn{4}{|c|}{ LIPTINITE (\%) } & \multirow{2}{*}{$\begin{array}{l}\text { MM } \\
(\%)\end{array}$} \\
\hline & & Tv & Dv & Gv & Tot & Sf & $\mathrm{Scl}$ & Inert & Tot & Res & Cut & Sub & Tot & \\
\hline \multirow{2}{*}{$\begin{array}{c}\text { Tanah Hitam } \\
\text { o/c }\end{array}$} & \multirow{2}{*}{$A$} & 47 & 33 & 5 & 85 & - & $\operatorname{tr}$ & $\operatorname{tr}$ & $\operatorname{tr}$ & - & 6 & 3 & 9 & 1 \\
\hline & & 21 & 57 & 10 & 88 & - & - & - & - & - & 1 & $\operatorname{tr}$ & 1 & $\operatorname{tr}$ \\
\hline \multirow{6}{*}{$\begin{array}{c}\text { Sawah Rasau } \\
\text { u/g }\end{array}$} & \multirow{6}{*}{ A } & 23 & 51 & 8 & 82 & $\operatorname{tr}$ & $\operatorname{tr}$ & $\operatorname{tr}$ & $\operatorname{tr}$ & 1 & 5 & 2 & 8 & 3 \\
\hline & & 23 & 50 & 13 & 86 & $\operatorname{tr}$ & $\operatorname{tr}$ & $\operatorname{tr}$ & $\operatorname{tr}$ & $\operatorname{tr}$ & 4 & 4 & 8 & 1 \\
\hline & & 29 & 56 & 10 & 95 & $\operatorname{tr}$ & $\operatorname{tr}$ & 1 & 1 & $\operatorname{tr}$ & 1 & $\operatorname{tr}$ & 1 & $\operatorname{tr}$ \\
\hline & & 19 & 58 & 10 & 87 & - & $\operatorname{tr}$ & $\operatorname{tr}$ & $\operatorname{tr}$ & $\operatorname{tr}$ & 5 & 1 & 6 & 1 \\
\hline & & 37 & 49 & 10 & 96 & - & 1 & 1 & 2 & $\operatorname{tr}$ & 1 & $\operatorname{tr}$ & 1 & - \\
\hline & & 38 & 48 & 5 & 91 & $\mathrm{tr}$ & 2 & 1 & 3 & 1 & 2 & tr & 3 & 1 \\
\hline \multirow{3}{*}{$\begin{array}{c}\text { Tanah Hitam } \\
\text { o/c }\end{array}$} & \multirow{3}{*}{ B1 } & 24 & 51 & 9 & 84 & $\operatorname{tr}$ & tr & 1 & 1 & 1 & 1 & 1 & 3 & 3 \\
\hline & & 24 & 49 & 16 & 89 & 1 & 1 & 1 & 3 & 1 & tr & tr & 1 & 2 \\
\hline & & 19 & 58 & 13 & 90 & $\mathrm{tr}$ & 2 & 1 & 3 & 1 & 1 & tr & 2 & 1 \\
\hline \multirow{2}{*}{$\begin{array}{c}\text { Sawah Rasau } \\
\mathrm{u} / \mathrm{g}\end{array}$} & \multirow{2}{*}{ B1 } & 14 & 65 & 5 & 84 & $\operatorname{tr}$ & 1 & $\operatorname{tr}$ & 1 & $\operatorname{tr}$ & 4 & $\operatorname{tr}$ & 4 & 6 \\
\hline & & 23 & 60 & 9 & 92 & $\mathrm{tr}$ & 1 & 1 & 2 & 1 & 2 & $\operatorname{tr}$ & 3 & 1 \\
\hline \multirow{2}{*}{$\begin{array}{c}\text { Tanah Hitam } \\
\text { o/c }\end{array}$} & \multirow{2}{*}{ B2 } & 19 & 65 & 9 & 93 & 1 & 2 & 1 & 4 & 1 & $\operatorname{tr}$ & $\operatorname{tr}$ & 1 & tr \\
\hline & & 28 & 51 & 11 & 90 & $\mathrm{tr}$ & 1 & 1 & 2 & tr & 4 & 1 & 5 & 1 \\
\hline \multirow{3}{*}{$\begin{array}{c}\text { Sawah Rasau } \\
\text { u/g }\end{array}$} & \multirow{3}{*}{ B2 } & 17 & 68 & 7 & 92 & 1 & 1 & 1 & 3 & 1 & 4 & $\operatorname{tr}$ & 5 & tr \\
\hline & & 66 & 25 & 5 & 96 & - & tr & $\operatorname{tr}$ & $\operatorname{tr}$ & 1 & 1 & $\operatorname{tr}$ & 2 & 1 \\
\hline & & 19 & 61 & 5 & 85 & $\mathrm{tr}$ & 1 & - & 1 & tr & 3 & - & 3 & 3 \\
\hline \multirow{7}{*}{$\begin{array}{c}\mathrm{BH} 7 \\
\text { Parambahan }\end{array}$} & \multirow{7}{*}{ B } & 41 & 47 & 7 & 95 & $\mathrm{tr}$ & - & 1 & 1 & 1 & 1 & 1 & 3 & tr \\
\hline & & 42 & 49 & 1 & 92 & $\operatorname{tr}$ & 1 & 1 & 2 & - & 3 & 1 & 4 & tr \\
\hline & & 39 & 42 & 14 & 95 & - & tr & - & $\operatorname{tr}$ & $\operatorname{tr}$ & 3 & $\operatorname{tr}$ & 3 & - \\
\hline & & 23 & 57 & 8 & 88 & 1 & 2 & 1 & 4 & 1 & 2 & - & 3 & 3 \\
\hline & & 26 & 54 & 6 & 86 & 1 & 2 & 1 & 4 & $\operatorname{tr}$ & 5 & $\operatorname{tr}$ & 5 & 3 \\
\hline & & 40 & 41 & 9 & 90 & $\operatorname{tr}$ & 2 & 1 & 3 & 1 & 2 & 1 & 4 & 2 \\
\hline & & 36 & 36 & 8 & 80 & 2 & 1 & - & 3 & $\operatorname{tr}$ & 3 & 2 & 5 & 11 \\
\hline \multirow{6}{*}{$\begin{array}{c}\text { Tanah Hitam } \\
\text { o/c }\end{array}$} & \multirow{6}{*}{ C } & 19 & 54 & 13 & 86 & $\mathrm{tr}$ & 3 & 3 & 6 & 1 & 1 & 1 & 3 & 1 \\
\hline & & 35 & 53 & 6 & 94 & - & $\operatorname{tr}$ & $\operatorname{tr}$ & $\operatorname{tr}$ & - & $\operatorname{tr}$ & 2 & 2 & tr \\
\hline & & 33 & 50 & 8 & 91 & - & 1 & 2 & 3 & - & 1 & 3 & 4 & - \\
\hline & & 99 & - & $\operatorname{tr}$ & 99 & 1 & $\mathrm{tr}$ & - & 1 & - & - & - & - & $\operatorname{tr}$ \\
\hline & & 99 & - & - & 99 & $\operatorname{tr}$ & 1 & - & 1 & - & - & - & - & tr \\
\hline & & 20 & 62 & 6 & 88 & 1 & 1 & tr & 2 & tr & 1 & tr & 1 & 7 \\
\hline \multirow{3}{*}{$\begin{array}{c}\text { Sawah Rasau } \\
\text { u/g }\end{array}$} & & 33 & 55 & 5 & 93 & $\operatorname{tr}$ & 1 & $\operatorname{tr}$ & 1 & 1 & 2 & 1 & 4 & - \\
\hline & C & 26 & 48 & 18 & 92 & $\operatorname{tr}$ & $\operatorname{tr}$ & $\operatorname{tr}$ & $\operatorname{tr}$ & $\operatorname{tr}$ & 4 & 2 & 6 & $\operatorname{tr}$ \\
\hline & & 32 & 50 & 12 & 94 & tr & $\operatorname{tr}$ & - & tr & 1 & 3 & 1 & 5 & $\operatorname{tr}$ \\
\hline $\mathrm{BH} 7$ & & 33 & 48 & 8 & 89 & 1 & 2 & $\operatorname{tr}$ & 3 & 1 & 3 & $\operatorname{tr}$ & 4 & 2 \\
\hline Parambahan & C & 38 & 45 & 8 & 91 & $\operatorname{tr}$ & 1 & 1 & 2 & 1 & 1 & $\operatorname{tr}$ & 2 & 4 \\
\hline
\end{tabular}



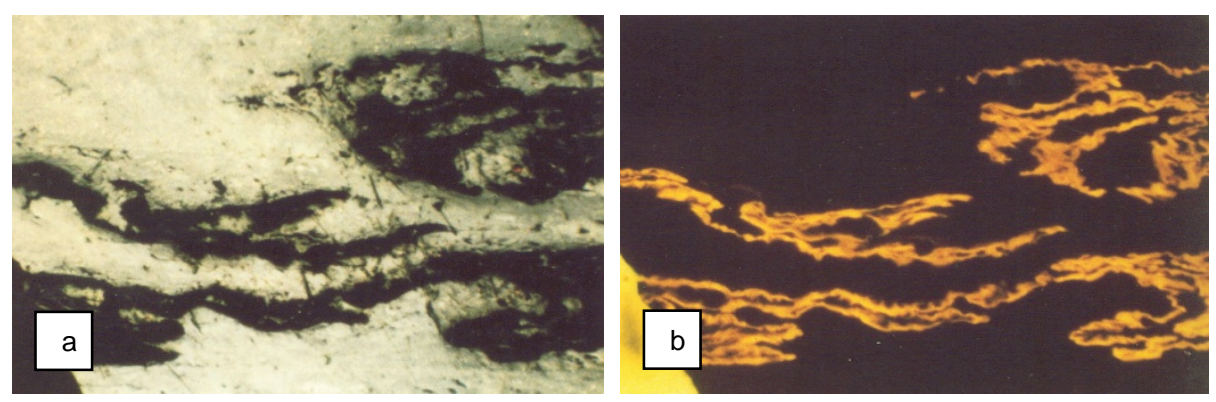

Figure 10 a). Cutinite in vitrinite. Palaeogene Ombilin coal, Rvmax: 0.65\%, field width: $0.28 \mathrm{~mm}$, reflected white light; b). As for Figure 10a, but in fluorescence mode
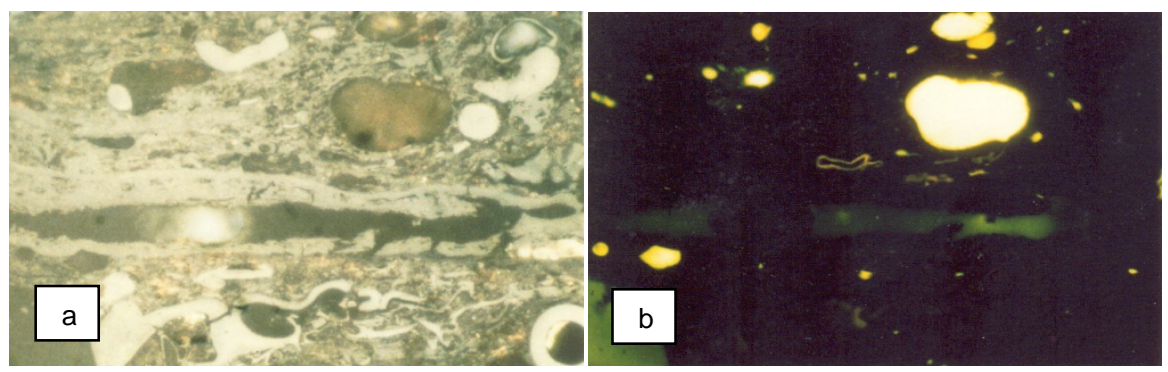

Figure $11 \mathrm{a}$ ). Detrovitrinite matrix with thin telovitrinite layers associated with semifusinite, sclerotinite, resinite and sporinite. Neogene Bukit Asam coal, Rvmax: $0.41 \%$, field width: $0.22 \mathrm{~mm}$, reflected white light; b). As for Figure 11a, but in fluorescence mode

The thermally affected coals have vitrinite content ranges from $90 \%$ to $98 \%$ with an average of $95 \%$. Telovitrinite is the main type of vitrinite. It is mostly structureless, although some have cell structure. In some cases, vitrinite is layered. Figures $12 \mathrm{a}, 12 \mathrm{~b}$ and $12 \mathrm{c}$ show textural features of vitrinite, commencing from coals unaffected by contact alteration through to the most strongly thermally affected coals.
The liptinite group constitutes a higher percentage in coals unaffected by contact alteration than in thermally affected coals. Liptinite content of the coals unaffected by contact alteration varies from $2 \%$ to $15 \%$ with an average of $7 \%$. Thermally affected coals have trace amounts of liptinite. The liptinites include mainly resinite, cutinite, liptodetrinite and suberinite with minor sporinite, fluorinite and rare exsudatinite.
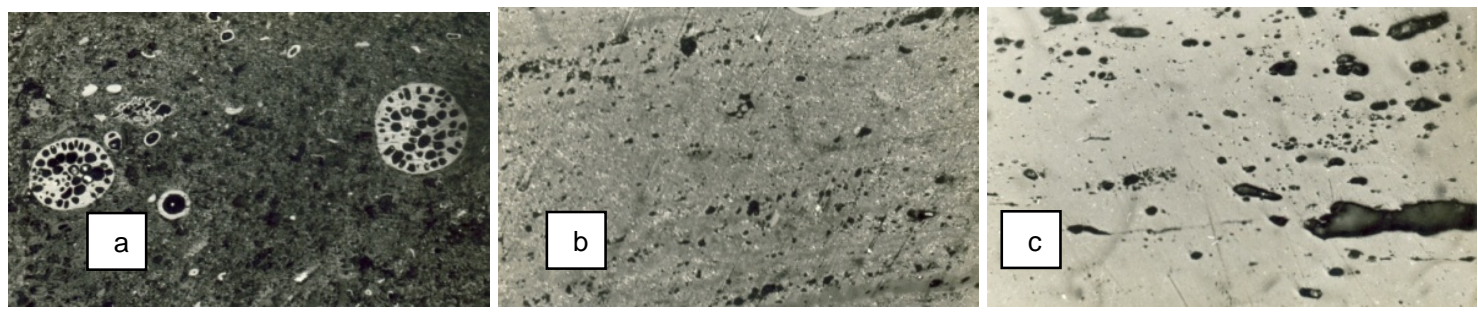

Figure $12 \mathrm{a}$ ). Detrovitrinite matrix and sclerotinite in coal not affected by contact alteration.

Neogene Bukit Asam coal, Rvmax: 0.41\%, field width: $0.36 \mathrm{~mm}$, reflected white light; b). Dense vitrinite

thermally affected coal. Neogene Bukit Asam coal, Rvmax: $0.89 \%$, reflected white light; c). Pores in vitrinite of thermally affected coal. Neogene Bukit Asam coal, Rvmax: 2.28\%, field width: 0.22mm, reflected white light 
Inertinite is generally rare in the Bukit Asam coals. Few coals contain more than 5\%. Semifusinite is commonly dominant over sclerotinite, inertodetrinite and fusinite. Micrinite and macrinite occur in some coals. Some cells of fungal sclerotinite are filled by resinite and mineral matter. Inertinite of the coals unaffected by contact alteration varies from $1 \%$ to $8 \%$ with an average of $3 \%$. The high inertinite contents in some seams confirm that aerobic conditions existed for deposition of that seam (Stach et al., 1982). Inertinite contents of all seams in the thermally affected coal suite are similar with an average of $3 \%$.

Mineral matter is rare in the Bukit Asam coals that are from trace to $5 \%$ with an average of $2 \%$. It is represented by clay occurring as pods and infilling cell lumens. Traces of pyrite are disseminated throughout the coals. Mineral matter content of thermally affected coals is slightly higher that that of coals unaffected by contact alteration.

To summarize, the liptinite and inertinite contents of the Bukit Asam coals are systematically related to vitrinite content. Liptinite and inertinite contents decrease with increase in vitrinite content. The liptinite content is not related to the inertinite content.

\section{Coal rank}

\section{Palaeogene/Ombilin}

Most of the Ombilin coals are high volatile bituminous rank (Rvmax of $0.62 \%$ to $0.77 \%$ ), although one coal is subbituminous (Rvmax of $0.55 \%$ ), as shown in Table 2 . This low vitrinite reflectance value is due to the presence of alginite. The rank of isolated coals in the open cut increases sharply into anthracite stage. This change is presumably associated with heating from a local intrusion. Slight variation in vitrinite reflectance occurs laterally due to the depth of burial.

\section{Neogene/Bukit Asam}

Vitrinite reflectance of the Bukit Asam coals ranges from $0.30 \%$ to $2.60 \%$ (Appendix 2). This wide range is due to the intrusion of andesite body in the area. Vitrinite reflectance of coal not affected by contact alteration ranges from $0.30 \%$ to $0.53 \%$. Otherwise, Rvmax of thermally altered coals varies between $0.69 \%$ and $2.60 \%$. Vitrinite reflectances between $0.40 \%$ and $0.50 \%$ are dominant at the Bukit Asam area. The pattern of vitrinite reflectance variation over the Bukit Asam Coalfield is similar for different seams. The main trend is for rank to increase towards the south of the area, which is in the vicinity of the andesite intrusion. To the north and to the west of the Bukit Asam area, vitrinite reflectance decreases gradually with Rvmax of $0.35 \%$ and $0.40 \%$. Vitrinite reflectance also shows a marked difference between the upper and lower seams. This difference is due to differences in stratigraphic position and the effect of heating from the andesite intrusion.

\section{B. Kalimantan}

Maceral analyses were carried out for Palaeogene and Neogene coals of East and South Kalimantan Coalfields. The Palaeogene and Neogene coals consist mostly of vitrinite and liptinite with rare inertinite. Vitrinite and inertinite contents decrease slightly from Neogene to Palaeogene coals. On the other hand, liptinite and mineral matter contents increase slightly from Neogene to Palaeogene coals. Liptinites in the Palaeogene coals have yellow to orange fluorescence, whereas Neogene coals have green to yellow fluorescence. Sporinite is dominant in Palaeogene coals but is rare in Neogene coals.

Generally, the rank of the Kalimantan Tertiary coals depends largely on the geological age. Reflectance measurements on the Palaeogene coals of East and South Kalimantan indicate that there is a substantial difference in rank between Palaeogene and Neogene coals. The Palaeogene coals are subbituminous to high volatile bituminous rank (Rvmax of $0.53 \%$ to $0.67 \%$ ); whereas Neogene coals are brown to subbituminous rank (Rvmax of $0.30 \%$ to $0.57 \%)$. The generally lower rank of the Neogene is a major difference between Neogene and Palaeogene coals. 
Table 2. Rank of the Palaeogene Ombilin coals

\begin{tabular}{|c|c|c|c|c|}
\hline LOCATION & SEAM & $\begin{array}{l}\text { Rvmax } \\
(\%)\end{array}$ & RANGE & RANK \\
\hline $\begin{array}{l}\text { Tanah Hitam } \\
\text { o/c }\end{array}$ & $A$ & $\begin{array}{l}0.63 \\
0.64\end{array}$ & $\begin{array}{l}0.57-0.69 \\
0.59-0.70\end{array}$ & $\begin{array}{l}\text { High volatile bituminous } \\
\text { High volatile bituminous }\end{array}$ \\
\hline $\begin{array}{c}\text { Sawah Rasau } \\
\text { u/g }\end{array}$ & $A$ & $\begin{array}{l}0.62 \\
0.68 \\
0.71 \\
0.64 \\
0.67 \\
0.68\end{array}$ & $\begin{array}{l}0.54-0.70 \\
0.62-0.74 \\
0.60-0.72 \\
0.58-0.70 \\
0.60-0.74 \\
0.60-0.82\end{array}$ & $\begin{array}{l}\text { High volatile bituminous } \\
\text { High volatile bituminous } \\
\text { High volatile bituminous } \\
\text { High volatile bituminous } \\
\text { High volatile bituminous } \\
\text { High volatile bituminous }\end{array}$ \\
\hline $\begin{array}{c}\text { Tanah Hitam } \\
\text { o/c }\end{array}$ & B1 & $\begin{array}{l}0.62 \\
0.64 \\
0.64\end{array}$ & $\begin{array}{l}0.57-0.69 \\
0.57-0.69 \\
0.56-0.70\end{array}$ & $\begin{array}{l}\text { High volatile bituminous } \\
\text { High volatile bituminous } \\
\text { High volatile bituminous }\end{array}$ \\
\hline $\begin{array}{c}\text { Sawah Rasau } \\
\text { u/g }\end{array}$ & B1 & $\begin{array}{l}0.55 \\
0.65\end{array}$ & $\begin{array}{l}0.46-0.63 \\
0.59-0.71\end{array}$ & $\begin{array}{c}\text { Sub-bituminous } \\
\text { High volatile bituminous }\end{array}$ \\
\hline $\begin{array}{l}\text { Tanah Hitam } \\
\text { o/c }\end{array}$ & B2 & $\begin{array}{l}0.68 \\
0.64\end{array}$ & $\begin{array}{l}0.61-0.75 \\
0.59-0.71\end{array}$ & $\begin{array}{l}\text { High volatile bituminous } \\
\text { High volatile bituminous }\end{array}$ \\
\hline $\begin{array}{c}\text { Sawah Rasau } \\
\mathrm{u} / \mathrm{g}\end{array}$ & B2 & $\begin{array}{l}0.71 \\
0.71 \\
0.62\end{array}$ & $\begin{array}{l}0.66-0.80 \\
0.61-0.80 \\
0.54-0.71\end{array}$ & $\begin{array}{l}\text { High volatile bituminous } \\
\text { High volatile bituminous } \\
\text { High volatile bituminous }\end{array}$ \\
\hline $\begin{array}{c}\mathrm{BH} 7 \\
\text { Parambahan }\end{array}$ & B & $\begin{array}{l}0.71 \\
0.70 \\
0.72 \\
0.75 \\
0.76 \\
0.77 \\
0.77\end{array}$ & $\begin{array}{l}0.65-0.78 \\
0.64-0.78 \\
0.67-0.78 \\
0.70-0.81 \\
0.72-0.87 \\
0.69-0.83 \\
0.72-0.82\end{array}$ & $\begin{array}{l}\text { High volatile bituminous } \\
\text { High volatile bituminous } \\
\text { High volatile bituminous } \\
\text { High volatile bituminous } \\
\text { High volatile bituminous } \\
\text { High volatile bituminous } \\
\text { High volatile bituminous }\end{array}$ \\
\hline $\begin{array}{c}\text { Tanah Hitam } \\
\text { o/c }\end{array}$ & $\mathrm{C}$ & $\begin{array}{l}0.64 \\
0.63 \\
0.62 \\
4.69 \\
3.39 \\
0.68\end{array}$ & $\begin{array}{l}0.56-0.73 \\
0.57-0.67 \\
0.57-0.66 \\
4.59-4.77 \\
3.30-3.51 \\
0.60-0.79\end{array}$ & $\begin{array}{l}\text { High volatile bituminous } \\
\text { High volatile bituminous } \\
\text { High volatile bituminous } \\
\text { Anthracite } \\
\text { Anthracite } \\
\text { High volatile bituminous }\end{array}$ \\
\hline $\begin{array}{c}\text { Sawah Rasau } \\
\text { u/g }\end{array}$ & $\mathrm{C}$ & $\begin{array}{l}0.64 \\
0.70 \\
0.68\end{array}$ & $\begin{array}{l}0.59-0.75 \\
0.65-0.77 \\
0.61-0.75\end{array}$ & $\begin{array}{l}\text { High volatile bituminous } \\
\text { High volatile bituminous } \\
\text { High volatile bituminous }\end{array}$ \\
\hline $\begin{array}{c}\mathrm{BH} 7 \\
\text { Parambahan }\end{array}$ & $\mathrm{C}$ & $\begin{array}{l}0.75 \\
0.77\end{array}$ & $\begin{array}{l}0.69-0.84 \\
0.73-0.81\end{array}$ & $\begin{array}{l}\text { High volatile bituminous } \\
\text { High volatile bituminous }\end{array}$ \\
\hline
\end{tabular}

\section{Coal type}

\section{Palaeogene/East and South Kalimantan}

Maceral analyses of different Palaeogene coals from East and South Kalimantan were carried out to illustrate a variation of the maceral composition (Table 3). Vitrinite is the dominant constituent of Palaeogene coals in East and South Kalimantan. The vitrinite content ranges from $80 \%$ to $88 \%$ with an average of $84 \%$ in East Kalimantan and between $76 \%$ and $94 \%$ with an average of $83 \%$ in South Kalimantan. Liptinite constitutes from $6 \%$ to $13 \%$ with an average of $10 \%$ in East Kalimantan and between 3\% and $19 \%$ with an average of $12 \%$ in South Kalimantan. Inertinite is rare with few samples containing more than $5 \%$. Mineral matter including clay and pyrite is common that is over $5 \%$ in some samples.

Telovitrinite occurs as thin isolated bands in thicker layers with a detrovitrinite matrix. Gelovitrinite, mainly corpovitrinite and porigelinite, is scattered throughout the coals. It is mostly associated with suberinite.

Liptinite of Palaeogene coals is dominated by cutinite, sporinite and resinite. However, suberinite and liptodetrinite are each dominant in some occurrences. Resinite 
constitutes up to $3 \%$ in East Kalimantan and over $7 \%$ in South Kalimantan. The resinite commonly occurs as rodlets and infilling cell lumens. It has yellow to orange fluorescence (Figures $13 \mathrm{a}$ and 13b). Cutinite that has weak yellow to orange fluorescence constitutes up to $6 \%$ of some coals. It is present as the thin cuticle. Sporinite is significantly high, up to $6 \%$ in South Kalimantan and 3\% in East Kalimantan.

Semifusinite, sclerotinite and inertodetrinite are the dominant inertinite macerals; whilst fusinite and micrinite are only present in some coals. Semifusinite commonly forms thin layers or lenses isolated in a detrovitrinite matrix. The semifusinite constitutes a trace to $2 \%$. Sclerotinite constitutes from $1 \%$ to $2 \%$ and is mostly disseminated throughout the coals. Inertodetrinite content ranges between a trace and $2 \%$. It is evenly disseminated throughout the coals. Fusinite occurs as isolated lenses.

Mineral matter including clay and pyrite is significantly common in Palaeogene coals. The mineral matter content ranges from $1 \%$ to $6 \%$ with an average of $3 \%$. However, some coals contain $11 \%$ of mineral matter. It mostly forms as pods disseminated throughout the coals and in some cases infilling cell lumens.

In summary, the liptinite and inertinite contents of East and South Kalimantan Palaeogene coals are systematically related to vitrinite content. Liptinite and inertinite contents decrease with increase in vitrinite content. The liptinite content is not related to the inertinite content.

\section{Neogene/East and South Kalimantan}

Petrographic studies on the coals from East and South Kalimantan indicate that all the coals have high vitrinite content, common liptinite and rare inertinite. Mineral matter, mainly clay and pyrite, is present.

Vitrinite of East Kalimantan Neogene coals ranges from $75 \%$ to $95 \%$ with average of $86 \%$ and in South Kalimantan, Neogene coals ranges from $87 \%$ to $90 \%$ with an average of $88 \%$ (Table 4 ). Vitrinite mostly occurs as thick layers with a detrovitrinite matrix interbedded with thin bands of telovitrinite. In some cases, thick massive telovitrinite is present with the detrovitrinitedominated coal. Gelovitrinite occurs as small discrete masses throughout the coals.

Table 3. Maceral composition of Palaeogene East and South Kalimantan coals

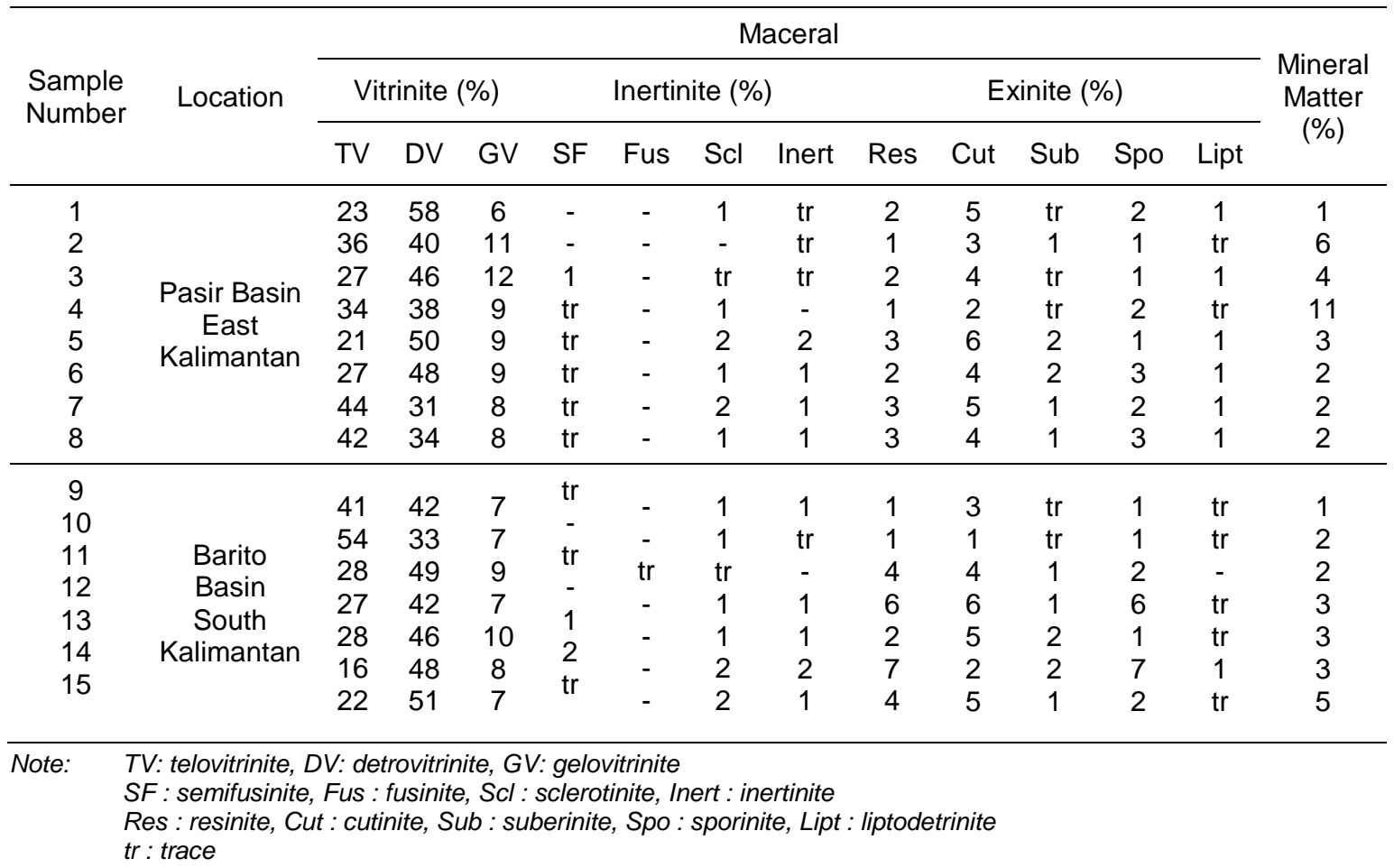




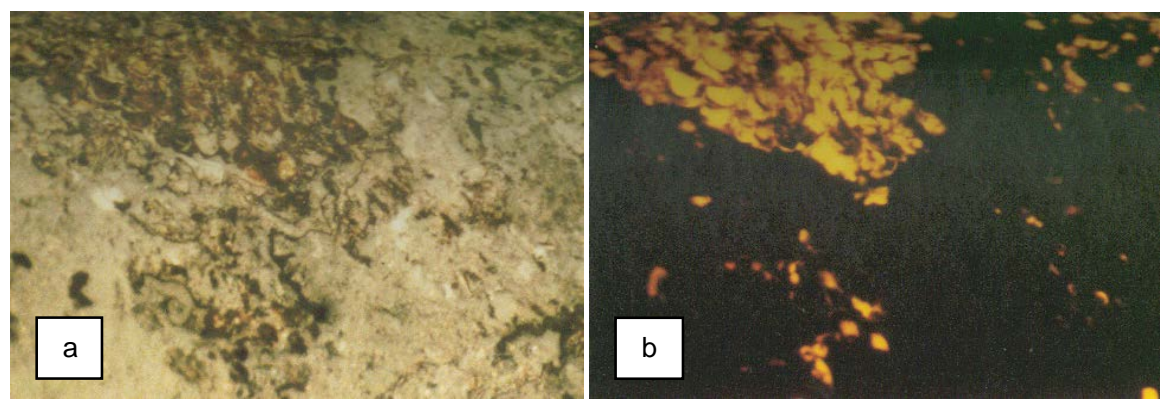

Figure $13 \mathrm{a}$ ). Resinite as rodlets and infilling cell lumens in vitrinite. Palaeogene East Kalimantan coal, Rvmax: $0.57 \%$, field width: $0.22 \mathrm{~mm}$, reflected white light; b). As for Figure 13a, but in fluorescence mode

Table 4. Maceral composition of Neogene East and South Kalimantan coals

\begin{tabular}{|c|c|c|c|c|c|c|c|c|c|c|c|c|c|c|}
\hline \multirow{3}{*}{$\begin{array}{l}\text { Sample } \\
\text { Number }\end{array}$} & \multirow{3}{*}{ Location } & \multicolumn{12}{|c|}{ Maceral } & \multirow{3}{*}{$\begin{array}{c}\text { Mineral } \\
\text { Matter } \\
(\%)\end{array}$} \\
\hline & & \multicolumn{3}{|c|}{ Vitrinite (\%) } & \multicolumn{4}{|c|}{ Inertinite (\%) } & \multicolumn{5}{|c|}{ Exinite (\%) } & \\
\hline & & TV & DV & GV & SF & Fus & $\mathrm{Scl}$ & Inert & Res & Cut & Sub & Spo & Fluo & \\
\hline 1 & & 25 & 47 & 15 & 1 & - & tr & 1 & 3 & 3 & 3 & 1 & tr & 1 \\
\hline 2 & & 25 & 50 & 12 & 2 & - & 1 & 2 & 3 & 3 & 1 & - & 1 & $\operatorname{tr}$ \\
\hline 3 & & 39 & 36 & 7 & 3 & - & 1 & 2 & 3 & 5 & 1 & $\operatorname{tr}$ & 2 & 1 \\
\hline 4 & & 46 & 29 & 8 & 1 & $\operatorname{tr}$ & 1 & - & 3 & 7 & 1 & - & 3 & 1 \\
\hline 5 & & 41 & 37 & 12 & 2 & $\operatorname{tr}$ & - & - & 2 & 2 & $\operatorname{tr}$ & - & 3 & 1 \\
\hline 6 & & 63 & 23 & 5 & $\operatorname{tr}$ & - & $\operatorname{tr}$ & $\operatorname{tr}$ & 2 & 1 & $\operatorname{tr}$ & - & 4 & 1 \\
\hline 7 & & 73 & 12 & 6 & 1 & - & tr & - & 3 & 1 & - & - & 2 & 1 \\
\hline 8 & & 46 & 29 & 8 & 1 & $\operatorname{tr}$ & $\operatorname{tr}$ & 1 & 2 & 7 & 1 & - & 2 & 2 \\
\hline 9 & & 40 & 38 & 6 & $\operatorname{tr}$ & - & 1 & 1 & 3 & 3 & 1 & $\operatorname{tr}$ & 3 & 1 \\
\hline 10 & Pasir & 31 & 44 & 15 & 1 & - & $\operatorname{tr}$ & 1 & 2 & 3 & 1 & - & 1 & 1 \\
\hline 11 & Basin & 43 & 41 & 11 & 1 & - & $\operatorname{tr}$ & 1 & $\operatorname{tr}$ & 1 & $\operatorname{tr}$ & $\operatorname{tr}$ & - & 1 \\
\hline 12 & East & 26 & 40 & 9 & 8 & 1 & 2 & 5 & 1 & 4 & 1 & - & - & 1 \\
\hline 13 & Kalimantan & 48 & 36 & 10 & 3 & - & - & 1 & $\operatorname{tr}$ & 1 & $\operatorname{tr}$ & - & $\operatorname{tr}$ & 1 \\
\hline 14 & & 26 & 58 & 8 & $\mathrm{tr}$ & - & $\operatorname{tr}$ & 1 & 1 & 3 & 1 & $\operatorname{tr}$ & $\operatorname{tr}$ & $\operatorname{tr}$ \\
\hline 15 & & 49 & 29 & 10 & 1 & - & tr & 2 & 3 & 3 & 1 & $\operatorname{tr}$ & $\operatorname{tr}$ & 1 \\
\hline 16 & & 53 & 30 & 6 & 1 & - & $\operatorname{tr}$ & 1 & 1 & 1 & - & 1 & 3 & 1 \\
\hline 17 & & 36 & 45 & 7 & 2 & 1 & - & 2 & 2 & 1 & 1 & $\mathrm{tr}$ & 1 & 1 \\
\hline 18 & & 45 & 37 & 9 & 2 & $\operatorname{tr}$ & 1 & 2 & 1 & 1 & $\operatorname{tr}$ & - & 1 & 1 \\
\hline 19 & & 16 & 53 & 9 & 4 & 1 & 1 & 3 & 2 & 3 & 1 & $\operatorname{tr}$ & 4 & 1 \\
\hline 20 & & 29 & 47 & 7 & 1 & - & $\operatorname{tr}$ & 1 & 3 & 8 & 1 & $\operatorname{tr}$ & 1 & 2 \\
\hline 21 & & 30 & 43 & 9 & - & - & - & - & 6 & 4 & 1 & - & 3 & 2 \\
\hline 22 & & 31 & 47 & 8 & 2 & - & 1 & 2 & 3 & 3 & tr & 1 & 1 & 1 \\
\hline 23 & Barito & 29 & 50 & 8 & tr & - & 1 & 1 & 4 & 1 & 1 & 1 & - & 2 \\
\hline 24 & Basin & 32 & 50 & 8 & $\begin{array}{l}1 \\
2\end{array}$ & - & 1 & 2 & 2 & tr & 2 & 1 & - & 1 \\
\hline 25 & $\begin{array}{l}\text { South } \\
\text { Kalimantan }\end{array}$ & 26 & 52 & 10 & 2 & 1 & 1 & 1 & 1 & 3 & $\operatorname{tr}$ & 1 & - & 1 \\
\hline
\end{tabular}

Liptinite of East Kalimantan Neogene coals varies between $2 \%$ and $15 \%$ with an average of $8 \%$ and in South Kalimantan, Neogene coals range from $5 \%$ to $8 \%$ with an average of $6 \%$. Resinite, cutinite and suberinite are the dominant liptinite macerals; and sporinite, liptodetrinite and fluorinite are rare. Exsudatinite occurs in trace amounts in a few coals. Resinite content varies between a trace and $6 \%$ with an average of $2 \%$. It mostly occurs as discrete small bodies (less than $0.06 \mathrm{~mm}$ ) throughout the coals. Some resinite infilling cell lumens occurs as distinct layers (Figures $14 \mathrm{a}$ and 14b). The resinite has low reflectance and fluoresces greenish yellow to yellow. 


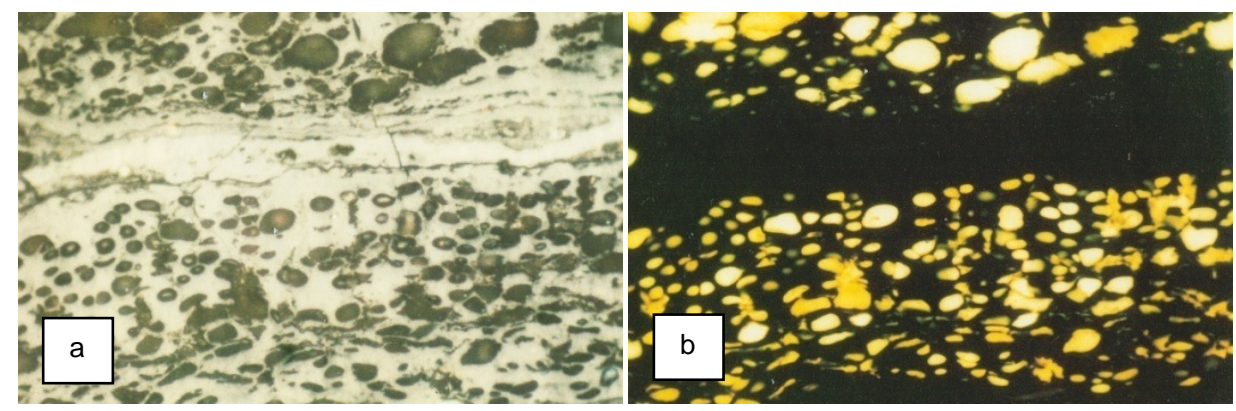

Figure $14 \mathrm{a})$. Resinite infilling cell lumens in distinct layers with telovitrinite. Neogene East Kalimantan coal, Rvmax: $0.46 \%$, field width: $0.28 \mathrm{~mm}$, reflected white light; b). As for Figure 14a, but in fluorescence mode

Inertinite is rare in Neogene coals, with few coals containing over $5 \%$. Semifusinite is the dominant inertinite maceral and it mostly occurs as thin layers or lenses isolated in detrovitrinite matrix. In some cases, the semifusinite occurs as thin to thick layers interbedded with thin bands of telovitrinite. Sclerotinite constitutes a trace to $1 \%$. It is commonly scattered throughout the coals, but some local concentrations occur. Inertodetrinite (up to $4 \%$ ) is disseminated throughout the coals. Fusinite, micrinite and macrinite are traces in some coals.

To summarize, the liptinite and inertinite contents of East and South Kalimantan Neogene coals are systematically related to vitrinite content. Liptinite and inertinite contents decrease with increase in vitrinite content. The liptinite content is not associated with inertinite content.

\section{Coal rank}

\section{Palaeogene/East and South Kalimantan}

Vitrinite reflectances of the East and South Kalimantan Palaeogene coals range between $0.53 \%$ and $0.67 \%$ (Table 5). As compared with South Kalimantan Palaeogene coals, the vitrinite reflectance of East Kalimantan Palaeogene coals is higher. Rvmax of East Kalimantan Palaeogene coals ranges from $0.57 \%$ to $0.67 \%$; whereas the South Kalimantan Palaeogene coals range between $0.53 \%$ and $0.64 \%$. Slight change in vitrinite reflectance in the South Kalimantan Palaeogene coals is due to the thicker cover/overburden on the high-rank coals. Vitrinite reflectance increases slightly from top to bottom of some individual seams in South Kalimantan. Vitrinite reflectances of
East Kalimantan coal seams do not show any trends. This means that the effect of temperature acting over a period of time did not vary within East Kalimantan coal seams and that type differences are small. However, in general, vitrinite reflectance trends of both East and South Kalimantan Palaeogene coals are the same. Rvmax increases slightly from top to base of the sequences.

\section{Neogene/East and South Kalimantan}

Vitrinite reflectances of East and South Kalimantan Neogene coals are similar (Rvmax of $0.30 \%$ to $0.47 \%$ ), as provided in Table 6. However, vitrinite reflectance is higher in some coals in East Kalimantan (Rvmax of $0.48 \%$ to $0.57 \%$ ). Vitrinite reflectance of both coals increases slightly from the top to the base of the sequence. This increase is caused by the greater thickness of cover over the seams showing high rank. Vitrinite reflectances of South Kalimantan Neogene coals show the same trend as that for the East Kalimantan Neogene coals.

\section{Java}

Maceral analyses of western Java/south Banten Palaeogene and Neogene coals indicate that vitrinite is the dominant maceral over liptinite and inertinite is rare. Mineral matter, mainly clay and pyrite, is significantly high.

The Palaeogene sequence contains the major coals of western Java/south Banten Coalfield. The Neogene coals are also present in northern Banten. Vitrinite reflectance of the Palaeogene south Banten coals is higher than that of the Neogene 
north Banten coals due to the andesite intrusion and stratigraphic aspect.

\section{Coal type}

Vitrinite of Palaeogene coals varies between $71 \%$ and $93 \%$ with an average of $88 \%$ and the vitrinite of Neogene coals ranges from $81 \%$ to $91 \%$ with an average of $87 \%$ (Table 7). The vitrinite mostly occurs as thick layers with a detrovitrinite matrix interbedded with thin layers of telovitrinite. Gelovitrinite including corpovitrinite and porigelinite is present throughout the coals.

Table 5. Rank of Palaeogene East and South Kalimantan coals

\begin{tabular}{cccc}
\hline $\begin{array}{c}\text { Sample } \\
\text { Number }\end{array}$ & Location & $\begin{array}{c}\text { Vitrinite } \\
\text { Reflectance } \\
\text { (Rvmax \%) }\end{array}$ & $\begin{array}{c}\text { Rank } \\
\text { (Australian Standard) }\end{array}$ \\
\hline 1 & & 0.63 & High volatile bituminous \\
2 & & 0.64 & High volatile bituminous \\
3 & Pasir Basin & 0.67 & High volatile bituminous \\
4 & 0.62 & High volatile bituminous \\
5 & East Kalimantan & 0.57 & Sub-bituminous \\
6 & & 0.61 & High volatile bituminous \\
7 & & 0.62 & High volatile bituminous \\
8 & & 0.62 & High volatile bituminous \\
\hline 9 & & 0.64 & High volatile bituminous \\
10 & & 0.64 & High volatile bituminous \\
11 & Barito Basin & 0.58 & Sub-bituminous \\
12 & South Kalimantan & 0.56 & Sub-bituminous \\
13 & & 0.60 & High volatile bituminous \\
14 & & 0.53 & Sub-bituminous \\
15 & & 0.55 & Sub-bituminous \\
\hline
\end{tabular}

Table 6. Rank of Neogene East and South Kalimantan coals (Australian standard)

\begin{tabular}{|c|c|c|c|}
\hline $\begin{array}{l}\text { Sample } \\
\text { Number }\end{array}$ & Location & $\begin{array}{c}\text { Vitrinite Reflectance } \\
\text { (Rvmax \%) }\end{array}$ & $\begin{array}{c}\text { Rank } \\
\text { (Australian Standard) }\end{array}$ \\
\hline 1 & & 0.47 & Sub-bituminous \\
\hline 2 & & 0.46 & Sub-bituminous \\
\hline 3 & & 0.41 & Sub-bituminous \\
\hline 4 & & 0.45 & Sub-bituminous \\
\hline 5 & & 0.45 & Sub-bituminous \\
\hline 6 & & 0.42 & Sub-bituminous \\
\hline 7 & & 0.40 & Sub-bituminous \\
\hline 8 & & 0.46 & Sub-bituminous \\
\hline 9 & & 0.43 & Sub-bituminous \\
\hline 10 & & 0.45 & Sub-bituminous \\
\hline 11 & Pasir Basin & 0.46 & Sub-bituminous \\
\hline 12 & East Kalimantan & 0.46 & Sub-bituminous \\
\hline 13 & & 0.46 & Sub-bituminous \\
\hline 14 & & 0.44 & Sub-bituminous \\
\hline 15 & & 0.45 & Sub-bituminous \\
\hline 16 & & 0.47 & Sub-bituminous \\
\hline 17 & & 0.47 & Sub-bituminous \\
\hline 18 & & 0.47 & Sub-bituminous \\
\hline 19 & & 0.43 & Sub-bituminous \\
\hline 20 & & 0.41 & Sub-bituminous \\
\hline 21 & & 0.48 & Sub-bituminous \\
\hline 22 & & 0.57 & Sub-bituminous \\
\hline 23 & Barito Basin & 0.30 & Brown coal \\
\hline 24 & South & 0.34 & Brown coal \\
\hline 25 & Kalimantan & 0.47 & Sub-bituminous \\
\hline
\end{tabular}


Resinite and cutinite are the dominant liptinite macerals; and suberinite, sporinite, liptodetrinite, fluorinite and exsudatinite (Figures $15 \mathrm{a}$ and $15 \mathrm{~b}$ ) are present in some coals. Sporinite occurs in trace amounts in Neogene coals. The sporinite has greenish yellow to yellow fluorescence. Resinite is the dominant liptinite maceral that is up to $7 \%$ in Neogene coals and up to $3 \%$ in Palaeogene coals). The resinite of Palaeogene coals mostly occurs as discrete small bodies (less than $0.06 \mathrm{~mm}$ ) of various shapes. In contrast, the resinite of Neogene coals is commonly concentrated in distinct layers. The resinite of both Palaeogene and Neogene coals has greenish yellow to yellow fluorescence.

Inertinite content of the Palaeogene coals of western Java is higher than that of Neogene coals. The inertinite maceral includes semifusinite, sclerotinite and inertodetrinite.
The semifusinite content of Palaeogene coals is up to $3 \%$ and that in Neogene coals is up to $1 \%$. Sclerotinite and inertodetrinite of Palaeogene coals are up to $2 \%$ and Neogene coals are up to $1 \%$. Both sclerotinite and inertodetrinite are scattered throughout the coals. Some cell lumens of the sclerotinite are infilled by mineral matter. Inertodetrinite occurs as small high reflecting particles (less than $0.02 \mathrm{~mm}$ ).

Mineral matter of Palaeogene coals (mainly clay and pyrite) varies between $1 \%$ and $6 \%$ with an average of $4 \%$. Some coals contain up to $13 \%$ mineral matter. Neogene coals constitute $1 \%$ mineral matter. The clay and pyrite (consists of framboidal and massive grain structures) mostly occur as pods disseminated throughout the coals. In some cases, they infill cell lumens.

Table 7. Maceral composition of the Palaeogene and Neogene western Java coals

\begin{tabular}{|c|c|c|c|c|c|c|c|c|c|c|c|c|c|c|}
\hline \multirow[t]{2}{*}{ Age } & \multirow[t]{2}{*}{ Location } & \multicolumn{4}{|c|}{ Vitrinite (\%) } & \multicolumn{4}{|c|}{ Inertinite (\%) } & \multicolumn{4}{|c|}{ Liptinite (\%) } & \multirow[t]{2}{*}{$\begin{array}{l}\text { MM } \\
(\%)\end{array}$} \\
\hline & & Tv & Dv & Gv & Tot & Sf & $\mathrm{Scl}$ & Inert & Tot & Res & Cut & Sub & Tot & \\
\hline \multirow{21}{*}{ Palaeogene } & \multirow{10}{*}{ Bayah } & 70 & 18 & 5 & 93 & $\operatorname{tr}$ & $\operatorname{tr}$ & 1 & 1 & 1 & 3 & - & 4 & 2 \\
\hline & & 60 & 22 & 5 & 87 & 1 & 1 & 1 & 3 & $\operatorname{tr}$ & 1 & - & 1 & 9 \\
\hline & & 36 & 47 & 5 & 88 & $\operatorname{tr}$ & $\operatorname{tr}$ & $\operatorname{tr}$ & $\operatorname{tr}$ & 1 & 2 & - & 3 & 8 \\
\hline & & 37 & 47 & 6 & 90 & 1 & 1 & 1 & 3 & 1 & 1 & - & 2 & 4 \\
\hline & & 39 & 48 & 5 & 92 & 1 & 1 & 1 & 3 & 1 & 1 & - & 2 & 3 \\
\hline & & 37 & 40 & 6 & 83 & $\mathrm{tr}$ & tr & $\operatorname{tr}$ & $\operatorname{tr}$ & 2 & 1 & - & 3 & 13 \\
\hline & & 44 & 36 & 8 & 88 & - & $\operatorname{tr}$ & $\operatorname{tr}$ & $\operatorname{tr}$ & - & 1 & 1 & 2 & 10 \\
\hline & & 47 & 33 & 8 & 88 & 2 & 1 & 1 & 4 & 1 & 1 & - & 2 & 6 \\
\hline & & 34 & 55 & 5 & 94 & - & 1 & $\operatorname{tr}$ & 1 & 1 & 3 & - & 4 & 2 \\
\hline & & 54 & 33 & 6 & 93 & $\operatorname{tr}$ & tr & - & $\operatorname{tr}$ & 1 & 1 & - & 2 & 4 \\
\hline & \multirow{5}{*}{ Cimandiri } & 35 & 41 & 15 & 91 & $\operatorname{tr}$ & 1 & - & 1 & 1 & $\operatorname{tr}$ & - & 1 & 7 \\
\hline & & 36 & 44 & 13 & 93 & $\operatorname{tr}$ & 1 & - & 1 & 1 & 1 & - & 2 & 3 \\
\hline & & 44 & 37 & 9 & 90 & 1 & 1 & 2 & 4 & 2 & 1 & 1 & 4 & 1 \\
\hline & & 45 & 33 & 11 & 89 & 1 & 1 & 1 & 3 & 3 & 1 & 1 & 5 & 2 \\
\hline & & 48 & 33 & 9 & 90 & $\operatorname{tr}$ & 1 & 1 & 2 & 3 & 1 & 1 & 5 & 2 \\
\hline & \multirow{6}{*}{ Cihideung } & 51 & 26 & 4 & 81 & 3 & 2 & 2 & 7 & 2 & 6 & $\operatorname{tr}$ & 8 & 4 \\
\hline & & 53 & 16 & 2 & 71 & 3 & 2 & 2 & 7 & 2 & 8 & $\operatorname{tr}$ & 10 & 10 \\
\hline & & 66 & 16 & 3 & 85 & 2 & 2 & 2 & 6 & tr & 7 & $\operatorname{tr}$ & 7 & 2 \\
\hline & & 82 & 9 & 1 & 92 & 1 & - & - & 1 & - & - & tr & $\operatorname{tr}$ & 7 \\
\hline & & 96 & $\operatorname{tr}$ & - & 96 & - & - & - & - & - & - & - & - & 4 \\
\hline & & 75 & 16 & 1 & 92 & 1 & 1 & $\operatorname{tr}$ & 2 & - & - & - & - & 6 \\
\hline \multirow{7}{*}{ Neogene } & \multirow{7}{*}{$\begin{array}{l}\text { Bojong- } \\
\text { manik }\end{array}$} & 27 & 45 & 8 & 80 & 1 & 1 & $\operatorname{tr}$ & 2 & 7 & 5 & 1 & 13 & 1 \\
\hline & & 31 & 43 & 9 & 83 & $\mathrm{tr}$ & 1 & $\operatorname{tr}$ & 1 & 6 & 4 & 1 & 11 & 1 \\
\hline & & 44 & 37 & 9 & 90 & 1 & 1 & $\operatorname{tr}$ & 2 & 3 & 2 & - & 5 & 1 \\
\hline & & 47 & 35 & 8 & 90 & 2 & 1 & $\operatorname{tr}$ & 3 & 3 & 2 & - & 5 & 1 \\
\hline & & 17 & 53 & 15 & 85 & 1 & 1 & tr & 2 & 7 & 3 & 1 & 11 & 1 \\
\hline & & 46 & 35 & 6 & 87 & - & 1 & - & 1 & 5 & 4 & - & 9 & 1 \\
\hline & & 19 & 56 & 12 & 87 & $\operatorname{tr}$ & 1 & $\operatorname{tr}$ & 1 & 6 & 2 & 1 & 9 & 1 \\
\hline
\end{tabular}

Notes: Tv : telovitrinite, Dv : detrovitrinite, Gv : gelovitrinite, Sf : semifusinite, Scl : sclerotinite, Inert : inertodetrinite Res : resinite, Cut : cutinite, Sub : suberinite, $M M$ : mineral matter, Tot : total 

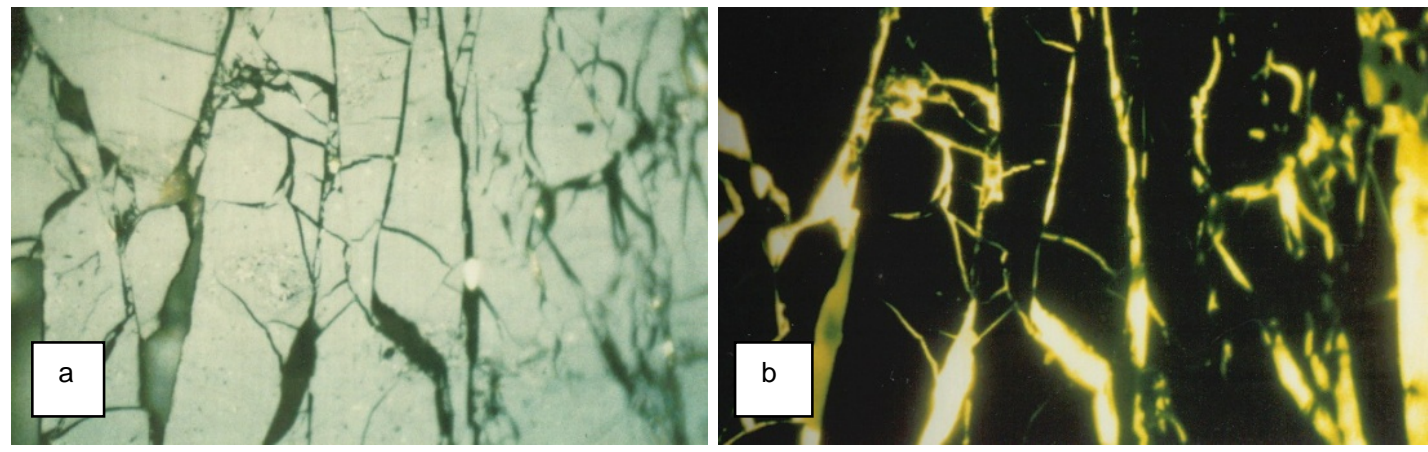

Figure $15 \mathrm{a}$ ). Exsudatinite infilling the fractures of vitrinite. Palaeogene western Java coal,

Rvmax: $0.65 \%$, field width: 0.28 , reflected white light; b). As for Figure 15a, but in fluorescence mode

In summary, the vitrinite, liptinite and inertinite contents of western Java Palaeogene and Neogene coals are systematically related to each other. Liptinite and inertinite contents decrease with increase in vitrinite content. The liptinite content tends to increase in inertinite content.

\section{Coal rank}

The Palaeogene coals range from subbituminous to high volatile bituminous rank (Rvmax of $0.53 \%$ to $0.83 \%$ ), as given in Table 8. The Neogene coals are brown to subbituminous rank (Rvmax of $0.34 \%$ to $0.41 \%)$. Vitrinite reflectance of Palaeogene coals in some areas of south Banten increases locally (Rvmax of $0.99 \%$ to $1.33 \%)$. This change is associated with an igneous intrusion.

Vitrinite reflectance increases from top to bottom of the Neogene and Palaeogene sequences. The change is caused by the greater thickness of cover over the lower coals.

\section{Discussion}

\section{Coal type}

The maceral compositions of the various western Indonesian Tertiary coals are slightly different from each other. Two factors can account for these variations, namely: intrusion effect and stratigraphic aspect (Amijaya and Littke, 2006; Susilawati and Ward, 2006; Santoso and Daulay, 2007; Daulay and Santoso, 2008; Sosrowidjojo and Saghafi, 2009). In the thermally affected coals from Ombilin and Bukit Asam Coalfields, liptinite generally cannot be distinguished from vitrinite (Santoso and Daulay, 2007; Daulay and Santoso, 2008). Therefore, both coals appear to contain a high proportion of vitrinite that ranges from $90 \%$ to 99\%. Nevertheless, thermally unaffected coals from both coalfields contain $75 \%$ to $90 \%$ vitrinite. Liptinite maceral is common in coals unaffected by contact alteration with some coals containing up to $15 \%$ liptinite. In contrast, thermally affected coals have trace amounts of liptinite. Fluorinite and exsudatinite are prominent in some of the western Indonesian coals and occur in association with vitrinite.

The exsudatinite occurrences indicate that significant hydrocarbon generation occurs within some terrestrial sourced organic matter at relatively low rank (Amijaya and Littke, 2006; Susilawati and Ward, 2006; Sosrowidjojo and Saghafi, 2009). Both thermally affected and unaffected coals contain rare inertinite with some coals containing up to $5 \%$. In some cases, coals with high inertinite content have a relatively high amount of mineral matter. It is suggested that this is the result of peat ablation in relatively oxidizing environments providing an unfavorable balance between the rate of accumulation of organic material and mineral matter. 
Table 8. Rank of the Palaeogene and Neogene western Java coals

\begin{tabular}{|c|c|c|}
\hline AGE & LOCATION & RANK \\
\hline \multirow{3}{*}{ Palaeogene } & Bayah & $\begin{array}{l}\text { High volatile bituminous } \\
\text { High volatile bituminous } \\
\text { High volatile bituminous } \\
\text { High volatile bituminous } \\
\text { High volatile bituminous } \\
\text { High volatile bituminous } \\
\text { High volatile bituminous } \\
\text { High volatile bituminous } \\
\text { High volatile bituminous } \\
\text { High volatile bituminous }\end{array}$ \\
\hline & Cimandiri & $\begin{array}{l}\text { High volatile bituminous } \\
\text { High volatile bituminous } \\
\text { High volatile bituminous } \\
\text { High volatile bituminous } \\
\text { High volatile bituminous }\end{array}$ \\
\hline & Cihideung & $\begin{array}{c}\text { Sub-bituminous } \\
\text { Sub-bituminous } \\
\text { Sub-bituminous } \\
\text { Sub-bituminous } \\
\text { Medium volatile bituminous } \\
\text { High volatile bituminous }\end{array}$ \\
\hline Neogene & Bojongmanik & $\begin{array}{l}\text { Sub-bituminous } \\
\text { Sub-bituminous } \\
\text { Brown coal } \\
\text { Brown coal } \\
\text { Brown coal } \\
\text { Brown coal } \\
\text { Brown coal }\end{array}$ \\
\hline
\end{tabular}

The western Indonesian Tertiary coals are divided into Palaeogene and Neogene coals. The most obvious trend for the Sumatran and western Java coals is the decrease in the proportion of liptinite and the increase in the proportion of vitrinite from Neogene to Palaeogene (Santoso and Daulay, 2007; Daulay and Santoso, 2008). In contrast, in the Kalimantan coals, the main trend is the increase in the proportion of liptinite and decrease in the proportion of vitrinite from Neogene to Palaeogene (Santoso and Daulay, 2005b, 2005c; Moore, Bowe and Nas, 2014; Santoso, 2015). Vitrinite in the coals unaffected by contact alteration (including Palaeogene and Neogene) comprises thick detrovitrinite matrix interbedded with thin bands of telovitrinite. In some cases, thin bands and lenses of telovitrinite are isolated in the detrovitrinite matrix. Vitrinite of thermally affected coals is mostly structureless, massive and few contain pores.

The dominance of vitrinite in western Indonesian Tertiary coals is indicative of forest type vegetation in a humid tropical zone, without significant dry events throughout. Vitrinite-rich coal in some cases has a high content of mineral matter. Belkin et al. (2009), Widodo et al. (2010) and Moore et al. (2014) noted that many seams deposited in areas of rapid subsidence have both high vitrinite content and a high mineral content present as discrete dirt bands.

\section{Coal rank}

Despite their short geological history, the western Indonesian Tertiary coals exhibit variable vitrinite reflectances, apparently due to igneous intrusion and stratigraphic factors (Amijaya and Littke, 2006; Susilawati and Ward, 2006; Santoso and Daulay, 2007; Daulay and Santoso, 2008; Belkin et al., 2009; Sosrowidjojo and Saghafi, 2009). From the petrographic characteristics, the western Indonesian Tertiary coals can be divided into three groups, namely Neogene, Palaeogene and thermally altered coals. The Neogene coals have vitrinite reflectances ranging from $0.30 \%$ to $0.57 \%$ and vitrinite contents ranging 
from $75 \%$ to $96 \%$. Most of the western Indonesian coals belong to this group. The Palaeogene coals have vitrinite reflectances between $0.53 \%$ and $0.83 \%$. Vitrinite content is similar to that of the Neogene coals. The Palaeogene coals include all coals in the Ombilin and Pasir Basins and some coals from the Barito Basin and the western Java Coalfields. The vitrinite reflectances range listed above of the two groups; refer to coals that have not been affected by local contact metamorphic effects (Amijaya and Littke, 2006; Susilawati and Ward, 2006; Belkin et al., 2009; Sosrowidjojo and Saghafi, 2009). The thermally altered generally have vitrinite reflectances of more than $0.83 \%$ and vitrinite contents of more than $85 \%$. Some coals from Bukit Asam, Ombilin and western Java Coalfields are in this group (Susilawati and Ward, 2006; Santoso and Daulay, 2007; Daulay and Santoso, 2008). In these areas, a more rapid and thorough alteration has taken place where bodies of igneous rock have intruded the Tertiary sequences. As a result, coal of lower rank has been metamorphosed to bituminous or anthracite rank. The extent of rank increase depends primarily on distance from the intruded igneous rocks. However, it may be related to size and temperature of the intrusion (Amijaya and Littke, 2006; Susilawati and Ward, 2006; Sosrowidjojo and Saghafi, 2009). Vitrinite reflectances of heat-affected coals of some areas are illustrated in (Table 9).

Table 9. Vitrinite reflectances of some western Indonesian heat-affected coals

\begin{tabular}{lcc}
\hline \multirow{2}{*}{ Coalfields } & \multicolumn{2}{c}{$\%$ Rvmax } \\
\cline { 2 - 3 } & $\begin{array}{c}\text { Unaffected } \\
\text { Coal }\end{array}$ & $\begin{array}{c}\text { Thermally } \\
\text { Affected Coal }\end{array}$ \\
\hline Bukit Asam & $0.30-0.53$ & $0.69-2.63$ \\
Ombilin & $0.55-0.77$ & $3.39-4.69$ \\
Western Java & $0.34-0.83$ & $0.99-1.23$ \\
\hline
\end{tabular}

The relationship between vitrinite reflectance and carbon content and specific energy is evident in both Palaeogene and Neogene coals. According to Santoso dan Daulay (2005a, 2005b), carbon content and specific energy of Palaeogene coals are in general higher than those of Neogene coals (Table 10).
Table 10. Chemical analyses and vitrinite reflectance of some western Indonesian coals

\begin{tabular}{cccc}
\hline \multirow{2}{*}{ Age } & \multicolumn{2}{c}{ Chemical Analyses } & Range \\
\cline { 2 - 3 } & $\begin{array}{c}\text { Carbon } \\
(\%)\end{array}$ & $\begin{array}{c}\text { Specific } \\
\text { Energy } \\
(\mathrm{kcal} / \mathrm{kg})\end{array}$ & $\begin{array}{c}\text { Rvmax } \\
(\%)\end{array}$ \\
\hline $\begin{array}{c}\text { Palaeogene } \\
\text { Neogene }\end{array}$ & 79.7 & 7,200 & $0.53-0.83$ \\
\hline
\end{tabular}

\section{CONCLUSION}

Coal type and rank characteristics of the western Indonesian Tertiary coals indicate the influence of geological setting on their characteristics. Indonesian coals of Palaeogene age were deposited in the intermontane basin and continental margin basin. They are interbedded with lacustrine and fluviatile deposits. Neogene coals were deposited in the back deep basin and continental margin basin. They range in sedimentary setting from limnic to deltaic and paralic. The palaeoclimate of Indonesia throughout the Tertiary was humid and tropical.

Vitrinite is the dominant maceral in the coals. It contains mostly detrovitrinite and telovitrinite with some minor gelovitrinite. Liptinite is common in the coals ranging from $5 \%$ to $10 \%$. Resinite is the dominant liptinite maceral in the coals. However, cutinite and suberinite are dominant in some occurrences. Sporinite and liptodetrinite are common and fluorinite is rare in the coals. The coals are also characterized by the presence of other liptinite macerals, like exsudatinite, alginite. Some of the western Indonesian coals, typically Neogene coals, contain more than $5 \%$ inertinite. The inertinite includes semifusinite, sclerotinite, fusinite and inertodetrinite. Mineral matter consisting mainly of clay and pyrite is rare in the coals, with few coals containing more than 5\%. Type characteristics of the western Indonesian coals more closely resemble each other. This suggests that the characteristics reflect the similarities in age, climate and general features of the peat environment. The proportion of inertinite in the coals suggests differences in the extent of oxidation during the peat stage. A high proportion of vitrinite in the coals indicates that the original plant material consisted 
essentially of woody plant tissue and the peatification process occurred under relatively wet reducing condition.

The western Indonesian Neogene coals are typically much lower in rank than the Palaeogene coals. The Indonesian Palaeogene coals not affected by contact alteration have vitrinite reflectances between $0.53 \%$ and $0.83 \%$; whilst the Neogene coals not affected by contact alteration range from $0.30 \%$ to $0.57 \%$. Most of the Neogene coals have vitrinite reflectances in the range of $0.40 \%$ to $0.50 \%$.

Vitrinite reflectance of the western Indonesian coals reveals significant increases with depth. Some seams exhibit an increase in vitrinite reflectance from seam top to bottom. In some of the western Indonesian coalfields, the coal seams are locally by igneous activity that has resulted in a wide range of higher rank coals (Rvmax of $0.69 \%$ to $4.69 \%$; bituminous to anthracite rank). In the proximity of the intrusions, very high lateral and vertical rank gradients are present.

From the above type and rank characteristics of the western Indonesian Tertiary coals, it is suggested that the coals are generally suited to use for direct combustion. The major utilization potential is power generation.

The rank of the coals is generally low for use as a single component charge in coal carbonization. However, significant reserves of the coals exist, typically Palaeogene coals, which could be added as a minor component with higher grade coking coals.

\section{ACKNOWLEDGMENTS}

This research work was carried out at the Laboratory of Coal Petrography, Research and Development Centre, Bandung. It was sponsored by the Ministry of Energy and Mineral Resources. This research was supervised by Prof. Bukin Daulay. His patient suggestion and overall assistance are gratefully acknowledged. Thanks also to Mrs. Nining Sudini Ningrum, M.Sc., Head of the Coal Petrography Laboratory and her staffs for the provision of the laboratory facilities during the research. The authors also wish to acknowledge Mr. Daldiri for drawing some figures in this paper.

\section{REFERENCES}

Amijaya, H. and Littke, R. (2006) "Properties of thermally metamorphosed coal from Tanjung Enim Area, South Sumatra Basin, Indonesia with special reference to the coalification path of macerals," International Journal of Coal Geology, 66(4), pp. 271-295. doi: 10.1016/j.coal.2005.07.008.

Australian Standard (1998) "Coal petrography. Part 2: maceral analysis." Strathfield, NSW, Australia.

Australian Standard (2000) "Coal petrography. Part 3: methods for microscopical determination of the reflectance of coal macerals." Strathfield, NSW, Australia.

Belkin, H. E., Tewalt, S. J., Hower, J. C., Stucker, J. D. and O'Keefe, J. M. K. (2009) "Geochemistry and petrology of selected coal samples from Sumatra, Kalimantan, Sulawesi, and Papua, Indonesia," International Journal of Coal Geology, 77(3-4), pp. 260-268. doi: 10.1016/j.coal.2008.08.001.

Darman, H. (2000) An Outline of the Geology of Indonesia. Edited by F. H. Sidi. Jakarta: Indonesian Association of Geologists.

Daulay, B. and Santoso, B. (2008) "Characteristics of selected Sumateran tertiary coals regarding their petrographic analyses," Indonesian Mining Journal, 11(10), pp. 1-18.

Daulay, B., Santoso, B. and Ningrum, N. S. (2015) "Evaluation of selected high rank coal in Kutai Basin, East Kalimantan relating to its coking properties," Indonesian Mining Journal, 18(1), pp. 110.

Daulay, B., Umar, D. F., Santoso, B. and Suganal (2010) "Strategy to maximize use of coal and associated gaseous fuels in South Sumatera Basin," Indonesian Mining Journal, 13(3), pp. 119-127.

Friederich, M. C., Moore, T. A. and Flores, R. M. (2016) "A regional review and new insights into SE Asian Cenozoic coalbearing sediments: Why does Indonesia have such extensive coal deposits?," International Journal of Coal Geology, 166(1 September 2016), pp. 2-35. doi: 10.1016/j.coal.2016.06.013. 
Hartono, U. (2012) Magmatism in Kalimantan. Bandung: Centre for Geological Survey.

Katili, J. A. (1980) Geotectonics of Indonesia-a modern view. Jakarta: Directorate General of Mines.

Koesoemadinata, R. P. (1978) "Sedimentary framework of Tertiary coal basins of Indonesia," in 3rd Regional Conference on Geology and Mineral Resources of SE Asia. Bangkok, pp. 621-639.

Moore, T. A., Bowe, M. and Nas, C. (2014) "High heat flow effects on a coalbed methane reservoir, East Kalimantan (Borneo), Indonesia," International Journal of Coal Geology, 131, pp. 7-31. doi: 10.1016/j.coal.2014.05.012.

Santoso, B. (2010) "Petrographic properties of Palaeogene southern Banten coal seams with regard to geologic aspects," Indonesian Mining Journal, 13(2), pp. 47-54.

Santoso, B. (2011) "Organic petrology of selected coal samples of Eocene Kuaro Formation from Pasir area-East Kalimantan," Indonesian Mining Journal, 14(3), pp. 146-153.

Santoso, B. (2015) Petrologi batubara Sumatera dan Kalimantan: jenis, peringkat dan aplikasi. Jakarta: LIPI Press.

Santoso, B. and Daulay, B. (2005a) "Factors affecting Tertiary coal quality (with particular case: Banten Coalfields)," Jurnal Teknologi Mineral dan Batubara, 13(33), pp. 1-9.

Santoso, B. and Daulay, B. (2005b) "Significance of type and rank of selected Kutai coals with respect to their utilisation characteristics," Indonesian Mining Journal, 8(3), pp. 1-12.

Santoso, B. and Daulay, B. (2005c) "Type and rank of selected Tertiary Kalimantan coals," Indonesian Mining Journal, 8(2), pp. 1-12.
Santoso, B. and Daulay, B. (2007) "Comparative petrography of Ombilin and Bayah coals related to their origin," Indonesian Mining Journal, 10(9), pp. 1-12.

Santoso, B. and Daulay, B. (2008) "Importance of organic petrology to type and rank of Miocene Asem-Asem coal, South Kalimantan," Indonesian Mining Journal, 11(12), pp. 1-10.

Sosrowidjojo, I. B. and Saghafi, A. (2009) "Development of the first coal seam gas exploration program in Indonesia: Reservoir properties of the Muaraenim Formation, south Sumatra," International Journal of Coal Geology, 79(4), pp. 145156. doi: 10.1016/j.coal.2009.07.002.

Stach, E., Mackowsky, M.-T., Teichmüller, M., Taylor, G. H., Chandra, D. and Teichmüller, R. (1982) Stach's textbook of coal petrology, Book.

Susilawati, R., Evans, P. N., Esterle, J. S., Robbins, S. J., Tyson, G. W., Golding, S. D. and Mares, T. E. (2015) "Temporal changes in microbial community composition during culture enrichment experiments with Indonesian coals," International Journal of Coal Geology, 137, pp. 66-76. doi: 10.1016/j.coal.2014.10.015.

Susilawati, R. and Ward, C. R. (2006) "Metamorphism of mineral matter in coal from the Bukit Asam deposit, south Sumatra, Indonesia," International Journal of Coal Geology, 68(3-4), pp. 171-195.

doi: 10.1016/j.coal.2006.02.003.

Widodo, S., Oschmann, W., Bechtel, A., Sachsenhofer, R. F., Anggayana, K. and Puettmann, W. (2010) "Distribution of sulfur and pyrite in coal seams from Kutai Basin (East Kalimantan, Indonesia): Implications for paleoenvironmental conditions," International Journal of Coal Geology, 81(3), pp. 151-162. doi: 10.1016/j.coal.2009.12.003. 
Appendix 1. Maceral composition of the Neogene Bukit Asam coals

\begin{tabular}{|c|c|c|c|c|c|c|c|c|c|c|c|c|c|c|}
\hline \multirow{2}{*}{ LOCATION } & \multirow[t]{2}{*}{ SEAM } & \multicolumn{4}{|c|}{ VITRINITE (\%) } & \multicolumn{4}{|c|}{ INERTINITE (\%) } & \multicolumn{4}{|c|}{ LIPTINITE (\%) } & \multirow{2}{*}{$\begin{array}{l}\text { MM } \\
(\%)\end{array}$} \\
\hline & & Tv & Dv & Gv & Tot & $\mathrm{Sf}$ & Scl & Inert & Tot & Res & Cut & Sub & Tot & \\
\hline \multirow{2}{*}{ Tapuan } & \multirow{2}{*}{ hanging } & 66 & 15 & 5 & 86 & 1 & $\operatorname{tr}$ & - & 1 & 3 & 1 & 1 & 5 & 2 \\
\hline & & 26 & 47 & 14 & 87 & 3 & $\operatorname{tr}$ & 1 & 4 & 1 & $\operatorname{tr}$ & 3 & 4 & 2 \\
\hline \multirow{3}{*}{ Banko } & \multirow{3}{*}{ hanging } & 31 & 52 & 5 & 88 & 2 & $\operatorname{tr}$ & $\operatorname{tr}$ & 2 & 2 & $\operatorname{tr}$ & 3 & 5 & 2 \\
\hline & & 47 & 38 & 6 & 91 & 1 & $\operatorname{tr}$ & - & 1 & 1 & $\operatorname{tr}$ & 2 & 3 & 3 \\
\hline & & 58 & 26 & 8 & 92 & 1 & $\operatorname{tr}$ & 1 & 2 & $\operatorname{tr}$ & - & 3 & 3 & 1 \\
\hline \multirow{3}{*}{ Air Laya o/c } & \multirow{3}{*}{ A1 } & 48 & 32 & 5 & 85 & 2 & - & $\operatorname{tr}$ & 2 & 1 & 6 & 2 & 3 & $\operatorname{tr}$ \\
\hline & & 54 & 35 & 5 & 94 & $\operatorname{tr}$ & $\operatorname{tr}$ & $\operatorname{tr}$ & $\operatorname{tr}$ & 1 & 1 & 1 & 1 & - \\
\hline & & 50 & 19 & 17 & 86 & 1 & $\operatorname{tr}$ & $\operatorname{tr}$ & 1 & 1 & 8 & $\operatorname{tr}$ & 2 & 1 \\
\hline \multirow{3}{*}{$\begin{array}{l}\text { SE Balong } \\
\text { Hijau o/c }\end{array}$} & \multirow{3}{*}{ A1 } & 31 & 42 & 22 & 95 & 1 & $\operatorname{tr}$ & - & 1 & 1 & 1 & $\operatorname{tr}$ & 2 & 1 \\
\hline & & 27 & 49 & 17 & 93 & 3 & $\operatorname{tr}$ & $\operatorname{tr}$ & 3 & $\operatorname{tr}$ & 1 & 1 & 2 & 1 \\
\hline & & 33 & 33 & 19 & 85 & 2 & $\operatorname{tr}$ & 1 & 3 & 5 & 2 & - & 7 & 1 \\
\hline \multirow{2}{*}{$\begin{array}{c}\text { SW Balong } \\
\text { Hijau o/c }\end{array}$} & \multirow{2}{*}{ A1 } & 97 & - & $\operatorname{tr}$ & 97 & 1 & 1 & - & 2 & - & - & - & - & 1 \\
\hline & & 97 & - & 1 & 98 & 1 & $\operatorname{tr}$ & - & 1 & - & - & - & - & 1 \\
\hline \multirow{3}{*}{$\begin{array}{c}\text { Muara Tiga } \\
\text { o/c }\end{array}$} & & 17 & 40 & 34 & 91 & 1 & 1 & - & 2 & 1 & 5 & $\operatorname{tr}$ & 6 & 1 \\
\hline & A1 & 97 & - & 1 & 98 & 1 & $\operatorname{tr}$ & - & 1 & - & - & - & - & 1 \\
\hline & & 56 & 33 & 7 & 96 & - & $\operatorname{tr}$ & - & $\operatorname{tr}$ & - & - & $\operatorname{tr}$ & $\operatorname{tr}$ & - \\
\hline & & 43 & 35 & 7 & 85 & 1 & $\operatorname{tr}$ & - & 1 & 1 & 1 & 6 & 8 & 4 \\
\hline Air Laway & A1 & 52 & 26 & 10 & 88 & 2 & $\operatorname{tr}$ & - & $\operatorname{tr}$ & 2 & - & 3 & 5 & 3 \\
\hline & & 57 & 19 & 10 & 86 & 2 & 1 & $\operatorname{tr}$ & 3 & 1 & 1 & 3 & 5 & 2 \\
\hline Tapuan & A1 & 57 & 22 & 12 & 91 & 1 & - & - & 1 & 1 & 1 & 3 & 5 & 1 \\
\hline & & 55 & 26 & 9 & 90 & 3 & 1 & - & 4 & 1 & 1 & 1 & 3 & 1 \\
\hline Air Laway & $\mathrm{A} 1$ & 52 & 27 & 9 & 88 & 1 & 1 & $\operatorname{tr}$ & 2 & 3 & 1 & 3 & 7 & 1 \\
\hline & & 77 & 10 & 5 & 92 & 4 & $\operatorname{tr}$ & - & 4 & 2 & $\operatorname{tr}$ & 2 & 4 & 1 \\
\hline Tapuan & $\mathrm{A} 1$ & 37 & 31 & 18 & 86 & 4 & $\operatorname{tr}$ & $\operatorname{tr}$ & 4 & 1 & - & 2 & 3 & 2 \\
\hline & & 34 & 36 & 11 & 81 & 5 & 1 & 1 & 7 & 1 & - & 3 & 4 & 2 \\
\hline & & 63 & 22 & 6 & 91 & 1 & $\operatorname{tr}$ & - & 2 & 1 & $\operatorname{tr}$ & 2 & 3 & 2 \\
\hline Air Laway & A1 & 36 & 39 & 9 & 84 & 2 & $\operatorname{tr}$ & 1 & 3 & 2 & $\operatorname{tr}$ & 2 & 4 & 2 \\
\hline & & 36 & 43 & 10 & 89 & 3 & $\operatorname{tr}$ & 1 & 4 & 1 & $\operatorname{tr}$ & 2 & 3 & 1 \\
\hline Suban & A1 & 97 & - & - & 97 & - & - & - & - & - & - & - & - & 2 \\
\hline suban o/c & AI & 96 & - & - & 96 & 2 & $\operatorname{tr}$ & - & 2 & - & - & - & - & 1 \\
\hline Air Laya o/c & A1 & 22 & 60 & 8 & 90 & 3 & 1 & 1 & 5 & 2 & $\operatorname{tr}$ & $\operatorname{tr}$ & 2 & 1 \\
\hline & & 46 & 24 & 15 & 85 & 4 & 1 & 1 & 6 & 2 & $\operatorname{tr}$ & 2 & 4 & 2 \\
\hline Air Laya & A1 & 84 & 5 & 2 & 91 & 3 & 1 & 1 & 5 & - & - & - & - & 5 \\
\hline & & 57 & 22 & 11 & 90 & 1 & $\operatorname{tr}$ & - & 1 & 1 & $\operatorname{tr}$ & 3 & 4 & 2 \\
\hline Suban & $\mathrm{A} 1$ & 33 & 48 & 12 & 92 & 5 & $\operatorname{tr}$ & $\operatorname{tr}$ & 5 & - & - & - & - & 1 \\
\hline Bukit Asam & $\mathrm{A} 1, \mathrm{~A} 2$ & 96 & - & 1 & 96 & $\operatorname{tr}$ & $\operatorname{tr}$ & - & $\operatorname{tr}$ & - & - & - & - & 2 \\
\hline Air Laya & A1 & 26 & 56 & 10 & 92 & 2 & $\operatorname{tr}$ & 1 & 3 & 1 & - & 1 & 2 & 1 \\
\hline Tapuan & A1 & 49 & 22 & 19 & 90 & 7 & $\operatorname{tr}$ & $\operatorname{tr}$ & 7 & - & - & - & - & 1 \\
\hline $\operatorname{Airl}=$ & & 38 & 40 & 8 & 86 & 2 & $\operatorname{tr}$ & 1 & 3 & 1 & $\operatorname{tr}$ & 2 & 3 & 4 \\
\hline Alr Laya & AI & 36 & 43 & 11 & 90 & 2 & $\operatorname{tr}$ & 1 & 3 & 1 & - & 1 & 2 & 1 \\
\hline & & 51 & 36 & 7 & 94 & 1 & $\operatorname{tr}$ & $\operatorname{tr}$ & 1 & 1 & - & 2 & 3 & 1 \\
\hline & & 66 & 21 & 8 & 95 & $\operatorname{tr}$ & $\operatorname{tr}$ & - & $\operatorname{tr}$ & $\operatorname{tr}$ & tr & 1 & 1 & 2 \\
\hline & & 65 & 14 & 12 & 91 & - & tr & $\operatorname{tr}$ & $\operatorname{tr}$ & 1 & $\operatorname{tr}$ & 3 & 4 & 2 \\
\hline Banko & $\mathrm{A} 1$ & 58 & 25 & 9 & 92 & $\operatorname{tr}$ & $\operatorname{tr}$ & - & $\mathrm{Tr}$ & 2 & 1 & 2 & 5 & 2 \\
\hline & & 50 & 35 & 7 & 92 & $\operatorname{tr}$ & 1 & - & 1 & $\operatorname{tr}$ & - & 5 & 5 & 2 \\
\hline & & 57 & 24 & 5 & 86 & $\operatorname{tr}$ & $\operatorname{tr}$ & - & $\operatorname{tr}$ & 5 & $\operatorname{tr}$ & 3 & 8 & 1 \\
\hline & & 45 & 26 & 6 & 77 & $\operatorname{tr}$ & $\operatorname{tr}$ & - & $\operatorname{tr}$ & 4 & 4 & 7 & 15 & 1 \\
\hline
\end{tabular}


INDONESIAN MINING JOURNAL Vol. 20, No. 1, April $2017: 1$ - 30

\begin{tabular}{|c|c|c|c|c|c|c|c|c|c|c|c|c|c|c|}
\hline \multirow{2}{*}{ LOCATION } & \multirow[t]{2}{*}{ SEAM } & \multicolumn{4}{|c|}{ VITRINITE (\%) } & \multicolumn{4}{|c|}{ INERTINITE (\%) } & \multicolumn{4}{|c|}{ LIPTINITE (\%) } & \multirow{2}{*}{$\begin{array}{l}\mathrm{MM} \\
(\%)\end{array}$} \\
\hline & & Tv & Dv & Gv & Tot & $\mathrm{Sf}$ & $\mathrm{Scl}$ & Inert & Tot & Res & Cut & Sub & Tot & \\
\hline \multirow{2}{*}{$\begin{array}{l}\text { SW Balong } \\
\text { Hijau o/c }\end{array}$} & \multirow{2}{*}{ A2 } & 96 & $\operatorname{tr}$ & 2 & 98 & $\operatorname{tr}$ & 1 & - & 1 & $\operatorname{tr}$ & - & - & $\operatorname{tr}$ & $\operatorname{tr}$ \\
\hline & & 96 & - & 1 & 97 & 1 & 1 & - & 2 & - & - & - & - & 1 \\
\hline \multirow{4}{*}{$\begin{array}{c}\text { Muara Tiga } \\
\text { o/c }\end{array}$} & \multirow{4}{*}{$\mathrm{A} 2$} & 31 & 44 & 10 & 85 & 10 & 1 & - & 11 & $\operatorname{tr}$ & 1 & $\operatorname{tr}$ & 1 & $\operatorname{tr}$ \\
\hline & & 30 & 37 & 11 & 78 & 11 & 1 & - & 12 & 4 & 2 & 1 & 7 & 1 \\
\hline & & 44 & 34 & 16 & 94 & 1 & $\operatorname{tr}$ & 1 & 2 & 1 & 2 & 1 & 4 & $\operatorname{tr}$ \\
\hline & & 38 & 27 & 23 & 88 & 5 & $\operatorname{tr}$ & tr & 5 & 1 & 2 & - & 3 & 1 \\
\hline \multirow{3}{*}{ Air Laway } & \multirow{3}{*}{ A2 } & 52 & 25 & 12 & 89 & 1 & $\operatorname{tr}$ & - & 1 & 1 & - & 4 & 5 & 3 \\
\hline & & 34 & 43 & 8 & 85 & 1 & 1 & - & 2 & 1 & $\operatorname{tr}$ & 6 & 7 & 4 \\
\hline & & 59 & 21 & 8 & 88 & 4 & 1 & - & 5 & 1 & 1 & 2 & 4 & 1 \\
\hline Tapuan & $\mathrm{A} 2$ & 44 & 33 & 11 & 88 & 2 & $\operatorname{tr}$ & $\operatorname{tr}$ & 2 & 2 & $\operatorname{tr}$ & 2 & 4 & 1 \\
\hline \multirow{3}{*}{ Air Laway } & \multirow{3}{*}{ A2 } & 55 & 20 & 12 & 87 & 3 & 1 & tr & 4 & $\operatorname{tr}$ & 2 & 2 & 4 & $\operatorname{tr}$ \\
\hline & & 62 & 20 & 8 & 90 & 1 & 1 & tr & 2 & $\operatorname{tr}$ & - & 2 & 2 & 2 \\
\hline & & 49 & 28 & 10 & 87 & 2 & $\operatorname{tr}$ & - & 2 & 3 & $\operatorname{tr}$ & 2 & 5 & 5 \\
\hline Tapuan & $\mathrm{A} 2$ & 59 & 21 & 9 & 89 & 1 & 1 & - & 2 & 2 & $\operatorname{tr}$ & 3 & 5 & 3 \\
\hline \multirow{4}{*}{ Air Laway } & \multirow{4}{*}{$\mathrm{A} 2$} & 27 & 43 & 16 & 86 & 5 & 1 & 1 & 7 & 1 & - & 2 & 3 & 1 \\
\hline & & 51 & 29 & 6 & 86 & 2 & 1 & - & 3 & 2 & 1 & 4 & 7 & 1 \\
\hline & & 25 & 55 & 11 & 91 & 3 & 1 & $\operatorname{tr}$ & 4 & 1 & - & 2 & 3 & 1 \\
\hline & & 39 & 39 & 11 & 89 & 3 & 1 & $\operatorname{tr}$ & 4 & $\operatorname{tr}$ & $\operatorname{tr}$ & 3 & 3 & 1 \\
\hline \multirow{2}{*}{ Suban o/c } & & 98 & - & - & 98 & 1 & $\operatorname{tr}$ & - & 1 & - & - & - & - & 1 \\
\hline & $A L$ & 97 & - & - & 97 & 1 & 1 & - & 2 & - & - & - & - & 1 \\
\hline & & 44 & 25 & 16 & 85 & 3 & 1 & 1 & 5 & 2 & - & 3 & 5 & 2 \\
\hline Alr Laya & $A 2$ & 92 & - & 2 & 94 & 3 & $\operatorname{tr}$ & - & 3 & - & - & - & - & 2 \\
\hline Suban & $\mathrm{A} 2$ & 87 & - & 3 & 90 & 5 & 1 & 1 & 7 & - & - & $\operatorname{tr}$ & $\operatorname{tr}$ & 2 \\
\hline Air Laya & $\mathrm{A} 2$ & 62 & 12 & 13 & 87 & 5 & $\operatorname{tr}$ & 1 & 6 & 1 & - & 1 & 2 & 2 \\
\hline Tapuan & $\mathrm{A} 2$ & 50 & 34 & 9 & 93 & 2 & - & 1 & 3 & $\operatorname{tr}$ & 1 & $\operatorname{tr}$ & 1 & 1 \\
\hline Air Laya & $\mathrm{A} 2$ & 35 & 42 & 8 & 85 & 4 & $\operatorname{tr}$ & 1 & 5 & 2 & 1 & 2 & 5 & 2 \\
\hline & & 31 & 46 & 9 & 96 & 3 & $\operatorname{tr}$ & 1 & 4 & 1 & - & 4 & 5 & 3 \\
\hline $\mathrm{o} / \mathrm{c}$ & B & 38 & 32 & 18 & 88 & 1 & - & $\operatorname{tr}$ & 1 & 2 & $\operatorname{tr}$ & 3 & 5 & 2 \\
\hline & & 40 & 35 & 15 & 90 & 1 & - & $\operatorname{tr}$ & 1 & 2 & $\operatorname{tr}$ & 3 & 5 & 2 \\
\hline & & 48 & 31 & 8 & 87 & 2 & 1 & - & 3 & 1 & 3 & $\operatorname{tr}$ & 4 & 2 \\
\hline Air Laway & B & 37 & 40 & 9 & 86 & 1 & 1 & tr & 2 & 3 & $\operatorname{tr}$ & 3 & 6 & 1 \\
\hline & & 54 & 26 & 4 & 84 & 1 & - & - & 1 & 6 & 3 & - & 9 & 1 \\
\hline Tapuan & B & 59 & 23 & 8 & 90 & 1 & $\operatorname{tr}$ & $\operatorname{tr}$ & 1 & 1 & $\operatorname{tr}$ & 2 & 3 & 2 \\
\hline & & 58 & 21 & 6 & 85 & 1 & 1 & - & 2 & 3 & $\operatorname{tr}$ & 3 & 6 & 3 \\
\hline & & 26 & 43 & 15 & 84 & 5 & 1 & 1 & 7 & 1 & - & 2 & 3 & 2 \\
\hline & & 21 & 59 & 6 & 86 & 2 & 1 & 1 & 4 & 2 & $\operatorname{tr}$ & 2 & 4 & 1 \\
\hline AIr Laway & B & 46 & 25 & 15 & 86 & 2 & 1 & $\operatorname{tr}$ & 3 & 1 & $\operatorname{tr}$ & 3 & 4 & 2 \\
\hline & & 18 & 64 & 8 & 90 & 2 & 1 & - & 3 & 2 & $\operatorname{tr}$ & 1 & 3 & 1 \\
\hline & & 27 & 48 & 15 & 90 & 3 & $\operatorname{tr}$ & 1 & 4 & 1 & - & 1 & 2 & 1 \\
\hline Air Laway & B1 & 53 & 22 & 10 & 85 & 2 & 1 & $\operatorname{tr}$ & 3 & 3 & 2 & 1 & 6 & 2 \\
\hline & & 96 & - & - & 96 & 2 & 1 & - & 3 & - & - & - & - & $\operatorname{tr}$ \\
\hline Suban o/c & B1 & 94 & $\operatorname{tr}$ & 2 & 96 & $\operatorname{tr}$ & $\operatorname{tr}$ & - & $\operatorname{tr}$ & - & - & - & - & 3 \\
\hline & & 94 & 1 & $\operatorname{tr}$ & 95 & 2 & 1 & - & 3 & - & - & - & - & 1 \\
\hline & & 47 & 26 & 13 & 86 & 4 & $\operatorname{tr}$ & $\operatorname{tr}$ & 4 & 2 & - & 2 & 4 & 2 \\
\hline Air Laya & B1 & 89 & - & 1 & 90 & 4 & 1 & - & 5 & - & - & - & - & 3 \\
\hline & & 54 & 29 & 6 & 89 & 1 & $\operatorname{tr}$ & - & $\operatorname{tr}$ & 2 & tr & 2 & 4 & 2 \\
\hline Suban & B1 & 82 & 7 & 7 & 96 & 1 & $\operatorname{tr}$ & tr & 1 & - & - & - & - & 3 \\
\hline Bukit Asam & B1 & 95 & - & 2 & 97 & 1 & $\operatorname{tr}$ & - & 1 & - & - & - & - & 2 \\
\hline
\end{tabular}


Petrographic Characteristics of Selected Tertiary Coals from Western ... Binarko Santoso

\begin{tabular}{|c|c|c|c|c|c|c|c|c|c|c|c|c|c|c|}
\hline \multirow{2}{*}{ LOCATION } & \multirow[t]{2}{*}{ SEAM } & \multicolumn{4}{|c|}{ VITRINITE (\%) } & \multicolumn{4}{|c|}{ INERTINITE (\%) } & \multicolumn{4}{|c|}{ LIPTINITE (\%) } & \multirow{2}{*}{$\begin{array}{l}\mathrm{MM} \\
(\%)\end{array}$} \\
\hline & & Tv & Dv & Gv & Tot & Sf & Scl & Inert & Tot & Res & Cut & Sub & Tot & \\
\hline Air Laya & B1 & 49 & 29 & 8 & 86 & 1 & - & $\operatorname{tr}$ & 1 & 1 & 1 & 4 & 6 & 4 \\
\hline Tapuan & B1 & 72 & 20 & 7 & 99 & $\operatorname{tr}$ & - & - & $\operatorname{tr}$ & - & - & - & - & 1 \\
\hline Air Laya & B1 & 35 & 49 & 7 & 91 & 2 & $\operatorname{tr}$ & 1 & 3 & 1 & - & 1 & 2 & 1 \\
\hline Banko & B1 & $\begin{array}{l}59 \\
41\end{array}$ & $\begin{array}{c}5 \\
34\end{array}$ & $\begin{array}{l}30 \\
10\end{array}$ & $\begin{array}{l}94 \\
85\end{array}$ & $\begin{array}{l}1 \\
2\end{array}$ & $\begin{array}{l}\operatorname{tr} \\
1\end{array}$ & $\begin{array}{l}- \\
-\end{array}$ & $\begin{array}{l}1 \\
3\end{array}$ & $\begin{array}{l}1 \\
2\end{array}$ & $\begin{array}{l}- \\
\operatorname{tr}\end{array}$ & $\begin{array}{l}2 \\
5\end{array}$ & $\begin{array}{l}3 \\
7\end{array}$ & $\begin{array}{l}1 \\
2\end{array}$ \\
\hline Air Laway & B1 & 49 & 27 & 11 & 87 & 3 & 1 & $\operatorname{tr}$ & 4 & 2 & 1 & 1 & 4 & 2 \\
\hline Air Laya & B2 & $\begin{array}{l}40 \\
75 \\
52\end{array}$ & $\begin{array}{l}40 \\
13 \\
22\end{array}$ & $\begin{array}{c}7 \\
4 \\
14\end{array}$ & $\begin{array}{l}87 \\
92 \\
88\end{array}$ & $\begin{array}{l}2 \\
3 \\
2\end{array}$ & $\begin{array}{l}1 \\
\mathrm{tr} \\
\mathrm{tr}\end{array}$ & $\begin{array}{c}\text { tr } \\
- \\
\operatorname{tr}\end{array}$ & $\begin{array}{l}3 \\
3 \\
2\end{array}$ & $\begin{array}{l}3 \\
- \\
2\end{array}$ & $\begin{array}{l}1 \\
- \\
\operatorname{tr}\end{array}$ & $\begin{array}{l}2 \\
- \\
2\end{array}$ & $\begin{array}{l}6 \\
- \\
4\end{array}$ & $\begin{array}{l}2 \\
4 \\
2\end{array}$ \\
\hline Suban & B2 & 95 & - & $\operatorname{tr}$ & 95 & 1 & 1 & $\operatorname{tr}$ & - & - & - & - & - & 2 \\
\hline Bukit Asam & B2 & 95 & - & 1 & 96 & $\operatorname{tr}$ & 1 & - & - & - & - & - & - & 3 \\
\hline Air Laya & B2 & 20 & 65 & 6 & 91 & 2 & 1 & $\operatorname{tr}$ & 3 & 1 & 1 & 1 & 3 & 1 \\
\hline Tapuan & B2 & 97 & - & - & 97 & tr & $\operatorname{tr}$ & - & $\operatorname{tr}$ & - & - & - & - & 2 \\
\hline Air Laya & B2 & $\begin{array}{l}30 \\
45\end{array}$ & $\begin{array}{l}48 \\
25\end{array}$ & $\begin{array}{l}10 \\
17\end{array}$ & $\begin{array}{l}88 \\
87\end{array}$ & $\begin{array}{l}4 \\
2\end{array}$ & $\begin{array}{l}\operatorname{tr} \\
\operatorname{tr}\end{array}$ & $\begin{array}{l}\operatorname{tr} \\
1\end{array}$ & $\begin{array}{l}4 \\
3\end{array}$ & $\begin{array}{l}2 \\
1\end{array}$ & $\begin{array}{l}1 \\
\operatorname{tr}\end{array}$ & $\begin{array}{l}2 \\
3\end{array}$ & $\begin{array}{l}5 \\
4\end{array}$ & $\begin{array}{l}1 \\
1\end{array}$ \\
\hline $\begin{array}{c}\text { Muara Tiga } \\
\text { o/c }\end{array}$ & C & $\begin{array}{l}97 \\
97\end{array}$ & $\begin{array}{l}- \\
-\end{array}$ & $\begin{array}{l}- \\
-\end{array}$ & $\begin{array}{l}97 \\
97\end{array}$ & $\begin{array}{l}1 \\
\operatorname{tr}\end{array}$ & $\begin{array}{l}1 \\
1\end{array}$ & $\begin{array}{l}- \\
-\end{array}$ & $\begin{array}{l}2 \\
1\end{array}$ & $\begin{array}{l}- \\
-\end{array}$ & $\begin{array}{l}- \\
-\end{array}$ & $\begin{array}{l}- \\
-\end{array}$ & $\begin{array}{l}- \\
-\end{array}$ & $\begin{array}{l}1 \\
1\end{array}$ \\
\hline Air Laway & C & $\begin{array}{c}54 \\
40 \\
63 \\
62 \\
51 \\
69 \\
30 \\
40 \\
47 \\
8\end{array}$ & $\begin{array}{l}26 \\
41 \\
19 \\
18 \\
33 \\
19 \\
39 \\
33 \\
33 \\
72\end{array}$ & $\begin{array}{c}6 \\
5 \\
5 \\
8 \\
7 \\
5 \\
14 \\
9 \\
9 \\
9\end{array}$ & $\begin{array}{l}86 \\
86 \\
87 \\
88 \\
91 \\
93 \\
83 \\
82 \\
89 \\
89\end{array}$ & $\begin{array}{l}2 \\
3 \\
2 \\
3 \\
1 \\
1 \\
4 \\
4 \\
1 \\
1\end{array}$ & $\begin{array}{l}\mathrm{tr} \\
\mathrm{tr} \\
1 \\
1 \\
\mathrm{tr} \\
1 \\
1 \\
1 \\
1 \\
\mathrm{tr}\end{array}$ & $\begin{array}{l}1 \\
\text { tr } \\
- \\
\text { tr } \\
\text { tr } \\
- \\
1 \\
1 \\
- \\
1\end{array}$ & $\begin{array}{l}3 \\
3 \\
3 \\
4 \\
1 \\
2 \\
6 \\
6 \\
2 \\
2\end{array}$ & $\begin{array}{l}1 \\
1 \\
2 \\
3 \\
2 \\
- \\
2 \\
2 \\
3 \\
1\end{array}$ & $\begin{array}{l}2 \\
\text { tr } \\
1 \\
\text { tr } \\
\text { tr } \\
- \\
\text { tr } \\
\text { tr } \\
\text { tr } \\
1\end{array}$ & $\begin{array}{l}\mathrm{tr} \\
3 \\
3 \\
2 \\
2 \\
1 \\
2 \\
2 \\
3 \\
2\end{array}$ & $\begin{array}{l}3 \\
4 \\
5 \\
5 \\
4 \\
1 \\
4 \\
4 \\
6 \\
3\end{array}$ & $\begin{array}{l}1 \\
2 \\
1 \\
\text { tr } \\
3 \\
4 \\
2 \\
2 \\
1 \\
2\end{array}$ \\
\hline Air Laya & C & $\begin{array}{l}47 \\
86 \\
20\end{array}$ & $\begin{array}{c}27 \\
- \\
59\end{array}$ & $\begin{array}{c}13 \\
4 \\
9\end{array}$ & $\begin{array}{l}87 \\
90 \\
86\end{array}$ & $\begin{array}{l}2 \\
3 \\
1\end{array}$ & $\begin{array}{l}- \\
\text { tr } \\
\text { tr }\end{array}$ & $\begin{array}{l}1 \\
- \\
1\end{array}$ & $\begin{array}{l}3 \\
3 \\
2\end{array}$ & $\begin{array}{l}2 \\
- \\
1\end{array}$ & $\begin{array}{l}\text { tr } \\
- \\
1\end{array}$ & $\begin{array}{l}2 \\
- \\
3\end{array}$ & $\begin{array}{l}4 \\
- \\
5\end{array}$ & $\begin{array}{l}2 \\
6 \\
2\end{array}$ \\
\hline Bukit Asam & C & 95 & - & 1 & 96 & 1 & $\operatorname{tr}$ & - & - & - & - & - & - & 2 \\
\hline Air Laya & C & $\begin{array}{l}39 \\
49 \\
36\end{array}$ & $\begin{array}{l}37 \\
32 \\
36\end{array}$ & $\begin{array}{c}14 \\
10 \\
9\end{array}$ & $\begin{array}{l}90 \\
91 \\
81\end{array}$ & $\begin{array}{l}2 \\
1 \\
5\end{array}$ & $\begin{array}{l}1 \\
1 \\
\operatorname{tr}\end{array}$ & $\begin{array}{l}- \\
1 \\
\operatorname{tr}\end{array}$ & $\begin{array}{l}3 \\
2 \\
\mathrm{tr}\end{array}$ & $\begin{array}{l}1 \\
\operatorname{tr} \\
1\end{array}$ & $\begin{array}{l}\text { tr } \\
- \\
3\end{array}$ & $\begin{array}{l}2 \\
3 \\
2\end{array}$ & $\begin{array}{l}3 \\
3 \\
6\end{array}$ & $\begin{array}{l}2 \\
2 \\
3\end{array}$ \\
\hline Banko & C & $\begin{array}{l}53 \\
51 \\
47\end{array}$ & $\begin{array}{l}29 \\
32 \\
28\end{array}$ & $\begin{array}{l}8 \\
5 \\
7\end{array}$ & $\begin{array}{l}90 \\
88 \\
82\end{array}$ & $\begin{array}{l}\text { tr } \\
1 \\
1\end{array}$ & $\begin{array}{l}1 \\
1 \\
\operatorname{tr}\end{array}$ & $\begin{array}{l}- \\
- \\
-\end{array}$ & $\begin{array}{l}1 \\
2 \\
1\end{array}$ & $\begin{array}{l}2 \\
2 \\
3\end{array}$ & $\begin{array}{l}- \\
\text { tr }\end{array}$ & $\begin{array}{l}2 \\
3 \\
8\end{array}$ & $\begin{array}{c}4 \\
5 \\
11\end{array}$ & $\begin{array}{l}2 \\
2 \\
2\end{array}$ \\
\hline
\end{tabular}

Notes: Tv : telovitrinite, Dv : detrovitrinite, Gv : gelovitrinite, Sf : semifusinite, Scl : sclerotinite, Inert : inertodetrinite, Res: : resinite, Cut : cutinite, Sub : suberinite, $M M$ : mineral matter, Tot : total o/c : open cut, u/g : underground, tr: trace 
INDONESIAN MINING JOURNAL Vol. 20, No. 1, April $2017: 1$ - 30

Appendix 2. Rank of the Neogene Bukit Asam coals

\begin{tabular}{|c|c|c|c|c|}
\hline LOCATION & SEAM & $\begin{array}{c}\text { Rvmax } \\
(\%)\end{array}$ & RANGE & RANK \\
\hline \multirow{2}{*}{ Tapuan } & \multirow{2}{*}{ Hanging } & 0.38 & $0.35-0.45$ & Brown coal \\
\hline & & 0.42 & $0.38-0.48$ & Sub-bituminous \\
\hline \multirow{3}{*}{ Banko } & \multirow{3}{*}{ Hanging } & 0.41 & $0.37-0.46$ & Sub-bituminous \\
\hline & & 0.36 & $0.30-0.41$ & Brown coal \\
\hline & & 0.38 & $0.34-0.43$ & Brown coal \\
\hline \multirow{3}{*}{ Air Laya o/c } & \multirow{3}{*}{$\mathrm{A} 1$} & 0.49 & $0.43-0.54$ & Sub-bituminous \\
\hline & & 0.47 & $0.40-0.52$ & Sub-bituminous \\
\hline & & 0.46 & $0.40-0.51$ & Sub-bituminous \\
\hline \multirow{3}{*}{$\begin{array}{c}\text { SE Balong } \\
\text { Hijau o/c }\end{array}$} & \multirow{3}{*}{ A1 } & 0.41 & $0.36-0.47$ & Sub-bituminous \\
\hline & & 0.41 & $0.36-0.52$ & Sub-bituminous \\
\hline & & 0.40 & $0.36-0.45$ & Sub-bituminous \\
\hline \multirow{2}{*}{$\begin{array}{l}\text { SW Balong } \\
\text { Hijau o/c }\end{array}$} & \multirow{2}{*}{$\mathrm{A} 1$} & 1.73 & $1.67-1.77$ & Low-volatile bituminous \\
\hline & & 1.61 & $1.52-1.66$ & Low-volatile bituminous \\
\hline \multirow{3}{*}{ Muara Tiga o/c } & \multirow{3}{*}{ A1 } & 0.42 & $0.37-0.49$ & Sub-bituminous \\
\hline & & 0.38 & $0.35-0.42$ & Brown coal \\
\hline & & 0.40 & $0.36-0.44$ & Sub-bituminous \\
\hline \multirow{3}{*}{ Air Laway } & \multirow{3}{*}{ A1 } & 0.37 & $0.33-0.41$ & Brown coal \\
\hline & & 0.37 & $0.33-0.43$ & Brown coal \\
\hline & & 0.42 & $0.38-0.46$ & Sub-bituminous \\
\hline Tapuan & A1 & 0.45 & $0.41-0.51$ & Sub-bituminous \\
\hline \multirow{3}{*}{ Air Laway } & \multirow{3}{*}{ A1 } & 0.41 & $0.38-0.47$ & Sub-bituminous \\
\hline & & 0.43 & $0.39-0.47$ & Sub-bituminous \\
\hline & & 0.43 & $0.39-0.47$ & Sub-bituminous \\
\hline Tapuan & A1 & 0.43 & $0.39-0.48$ & Sub-bituminous \\
\hline \multirow{4}{*}{ Air Laway } & \multirow{4}{*}{ A1 } & 0.39 & $0.35-0.42$ & Brown coal \\
\hline & & 0.35 & $0.31-0.40$ & Brown coal \\
\hline & & 0.36 & $0.32-0.39$ & Brown coal \\
\hline & & 0.40 & $0.36-0.44$ & Sub-bituminous \\
\hline & & 2.34 & $2.29-2.44$ & Semi-anthracite \\
\hline Suban o/c & A1 & 2.32 & $2.21-2.42$ & Semi-anthracite \\
\hline Air Laya o/c & A1 & 0.41 & $0.37-0.47$ & Sub-bituminous \\
\hline & & 0.44 & $0.39-0.50$ & Sub-bituminous \\
\hline Air Laya & A1 & 1.44 & $1.39-1.49$ & Medium-volatile bituminous \\
\hline & & 0.43 & $0.39-0.47$ & Sub-bituminous \\
\hline Suban & A1 & 0.84 & $0.77-0.91$ & High-volatile bituminous \\
\hline Bukit Asam & $\mathrm{A} 1+\mathrm{A} 2$ & 1.99 & $1.85-2.06$ & Low-volatile bituminous \\
\hline Air Laya & A1 & 0.45 & $0.40-0.52$ & Sub-bituminous \\
\hline Tapuan & A1 & 0.77 & $0.70-0.87$ & High-volatile bituminous \\
\hline & & 0.42 & $0.38-0.46$ & Sub-bituminous \\
\hline Aır Laya & A1 & 0.42 & $0.37-0.50$ & Sub-bituminous \\
\hline & & 0.44 & $0.41-0.49$ & Sub-bituminous \\
\hline & & 0.40 & $0.36-0.44$ & Sub-bituminous \\
\hline & & 0.37 & $0.33-0.42$ & Brown coal \\
\hline Banko & A1 & 0.42 & $0.37-0.48$ & Sub-bituminous \\
\hline & & 0.41 & $0.35-0.47$ & Sub-bituminous \\
\hline & & 0.43 & $0.38-0.47$ & Sub-bituminous \\
\hline & & 0.45 & $0.39-0.52$ & Sub-bituminous \\
\hline SW Balong & & 1.00 & $0.93-1.04$ & High-volatile bituminous \\
\hline Hijau o/c & A2 & 0.98 & $0.93-1.03$ & High-volatile bituminous \\
\hline & & 0.41 & $0.36-0.45$ & Sub-bituminous \\
\hline Muara Tiga & A2 & 0.40 & $0.37-0.44$ & Sub-bituminous \\
\hline IMuara IIga & $A 2$ & 0.40 & $0.36-0.45$ & Sub-bituminous \\
\hline & & 0.40 & $0.36-0.47$ & Sub-bituminous \\
\hline & & 0.42 & $0.37-0.47$ & Sub-bituminous \\
\hline Air Laway & $\mathrm{A} 2$ & 0.38 & $0.35-0.41$ & Brown coal \\
\hline & & 0.44 & $0.39-0.48$ & Sub-bituminous \\
\hline Tapuan & $\mathrm{A} 2$ & 0.46 & $0.39-0.51$ & Sub-bituminous \\
\hline
\end{tabular}


Petrographic Characteristics of Selected Tertiary Coals from Western ... Binarko Santoso

\begin{tabular}{|c|c|c|c|c|}
\hline LOCATION & SEAM & $\begin{array}{c}\text { Rvmax } \\
(\%)\end{array}$ & RANGE & RANK \\
\hline \multirow{3}{*}{ Air Laway } & \multirow{3}{*}{ A2 } & 0.43 & $0.38-0.48$ & Sub-bituminous \\
\hline & & 0.41 & $0.38-0.45$ & Sub-bituminous \\
\hline & & 0.45 & $0.40-0.48$ & Sub-bituminous \\
\hline Tapuan & $\mathrm{A} 2$ & 0.42 & $0.38-0.47$ & Sub-bituminous \\
\hline \multirow{4}{*}{ Air Laway } & \multirow{4}{*}{ A2 } & 0.39 & $0.36-0.42$ & Brown coal \\
\hline & & 0.39 & $0.36-0.42$ & Brown coal \\
\hline & & 0.41 & $0.35-0.44$ & Sub-bituminous \\
\hline & & 0.40 & $0.36-0.44$ & Sub-bituminous \\
\hline \multirow{2}{*}{ Suban o/c } & \multirow{2}{*}{ A2 } & 2.32 & $2.24-2.45$ & Semi-anthracite \\
\hline & & 2.18 & $2.10-2.23$ & Semi-anthracite \\
\hline \multirow{3}{*}{ Air Laya } & \multirow{3}{*}{ A2 } & 0.44 & $0.37-0.50$ & Sub-bituminous \\
\hline & & 1.26 & $1.12-1.32$ & Medium-volatile bituminous \\
\hline & & 0.43 & $0.38-0.49$ & Sub-bituminous \\
\hline Suban & A2 & 0.89 & $0.80-0.95$ & High-volatile bituminous \\
\hline Air Laya & $\mathrm{A} 2$ & 0.48 & $0.43-0.55$ & Sub-bituminous \\
\hline Tapuan & A2 & 0.69 & $0.61-0.75$ & High-volatile bituminous \\
\hline Air Laya & $\mathrm{A} 2$ & 0.44 & $0.40-0.49$ & Sub-bituminous \\
\hline \multirow{3}{*}{ Muara Tiga o/c } & \multirow{3}{*}{ B } & 0.43 & $0.38-0.47$ & Sub-bituminous \\
\hline & & 0.44 & $0.39-0.49$ & Sub-bituminous \\
\hline & & 0.40 & $0.36-0.45$ & Sub-bituminous \\
\hline \multirow{3}{*}{ Air Laway } & \multirow{3}{*}{ B } & 0.39 & $0.36-0.42$ & Brown coal \\
\hline & & 0.43 & $0.38-0.47$ & Sub-bituminous \\
\hline & & 0.42 & $0.38-0.49$ & Sub-bituminous \\
\hline Tapuan & B & 0.44 & $0.39-0.51$ & Sub-bituminous \\
\hline \multirow{7}{*}{ Air Laway } & \multirow{7}{*}{ B } & 0.41 & $0.38-0.46$ & Sub-bituminous \\
\hline & & 0.40 & $0.37-0.44$ & Sub-bituminous \\
\hline & & 0.40 & $0.37-0.45$ & Sub-bituminous \\
\hline & & 0.39 & $0.31-0.40$ & Brown coal \\
\hline & & 0.41 & $0.37-0.45$ & Sub-bituminous \\
\hline & & 0.41 & $0.37-0.47$ & Sub-bituminous \\
\hline & & 0.43 & $0.39-0.48$ & Sub-bituminous \\
\hline \multirow{3}{*}{ Suban o/c } & \multirow{3}{*}{ B1 } & 2.60 & $2.50-2.70$ & Anthracite \\
\hline & & 2.41 & $2.30-2.53$ & Semi-anthracite \\
\hline & & 2.55 & $2.47-2.63$ & Anthracite \\
\hline \multirow{3}{*}{ Air Laya } & \multirow{3}{*}{ B1 } & 0.43 & $0.39-0.49$ & Sub-bituminous \\
\hline & & 1.70 & $1.64-1.75$ & Low-volatile bituminous \\
\hline & & 0.43 & $0.39-0.49$ & Sub-bituminous \\
\hline Suban & B1 & 1.07 & $1.01-1.13$ & High-volatile bituminous \\
\hline Bukit Asam & B1 & 2.19 & $2.09-2.29$ & Semi-anthracite \\
\hline Air Laya & B1 & 0.48 & $0.41-0.59$ & Sub-bituminous \\
\hline Tapuan & B1 & 1.40 & $1.34-1.52$ & Medium-volatile bituminous \\
\hline Air Laya & B1 & 0.44 & $0.40-0.49$ & Sub-bituminous \\
\hline & 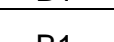 & 0.42 & $0.38-0.49$ & Sub-bituminous \\
\hline Banko & B1 & 0.53 & $0.43-0.64$ & Sub-bituminous \\
\hline Air Laway & $\mathrm{B} 2$ & 0.43 & $0.39-0.49$ & Sub-bituminous \\
\hline & & 0.49 & $0.42-0.56$ & Sub-bituminous \\
\hline Air Laya & B2 & 1.72 & $1.66-1.78$ & Low-volatile bituminous \\
\hline & & 0.44 & $0.39-0.51$ & Sub-bituminous \\
\hline Suban & B2 & 1.25 & $1.20-1.33$ & Medium-volatile bituminous \\
\hline Bukit Asam & B2 & 2.25 & $2.17-2.35$ & Semi-anthracite \\
\hline Air Laya & B2 & 0.51 & $0.44-0.57$ & Sub-bituminous \\
\hline Tapuan & B2 & 2.05 & $1.97-2.12$ & Semi-anthracite \\
\hline & & 0.45 & $0.40-0.52$ & Sub-bituminous \\
\hline Air Laya & B2 & 0.42 & $0.38-0.47$ & Sub-bituminous \\
\hline Muara Tiga o/c & $\mathrm{C}$ & 1.46 & $1.40-1.54$ & Medium-volatile bituminous \\
\hline & & 1.55 & $1.46-1.62$ & Low-volatile bituminous \\
\hline Muara Tiga & C & 1.53 & $1.48-1.58$ & Low-volatile bituminous \\
\hline
\end{tabular}


INDONESIAN MINING JOURNAL Vol. 20, No. 1, April $2017: 1$ - 30

\begin{tabular}{|c|c|c|c|c|}
\hline LOCATION & SEAM & $\begin{array}{c}\text { Rvmax } \\
(\%)\end{array}$ & RANGE & RANK \\
\hline \multirow{11}{*}{ Air Laway } & \multirow{11}{*}{ C } & 0.42 & $0.37-0.48$ & Sub-bituminous \\
\hline & & 0.43 & $0.38-0.47$ & Sub-bituminous \\
\hline & & 0.44 & $0.39-0.48$ & Sub-bituminous \\
\hline & & 0.47 & $0.41-0.54$ & Sub-bituminous \\
\hline & & 0.45 & $0.40-0.50$ & Sub-bituminous \\
\hline & & 0.89 & $0.81-0.97$ & High-volatile bituminous \\
\hline & & 0.42 & $0.38-0.47$ & Sub-bituminous \\
\hline & & 0.41 & $0.35-0.48$ & Sub-bituminous \\
\hline & & 0.45 & $0.39-0.50$ & Sub-bituminous \\
\hline & & 0.42 & $0.39-0.47$ & Sub-bituminous \\
\hline & & 0.45 & $0.40-0.51$ & Sub-bituminous \\
\hline \multirow{2}{*}{ Air Laya } & \multirow{2}{*}{ C } & 1.78 & $1.66-1.85$ & Low-volatile bituminous \\
\hline & & 0.45 & $0.39-0.50$ & Sub-bituminous \\
\hline Bukit Asam & C & 2.28 & $2.19-2.36$ & Semi-anthracite \\
\hline \multirow{3}{*}{ Air Laya } & \multirow{3}{*}{ C } & 0.51 & $0.46-0.58$ & Sub-bituminous \\
\hline & & 0.47 & $0.40-0.54$ & Sub-bituminous \\
\hline & & 0.43 & $0.38-0.50$ & Sub-bituminous \\
\hline \multirow{3}{*}{ Banko } & \multirow{3}{*}{ C } & 0.41 & $0.36-0.50$ & Sub-bituminous \\
\hline & & 0.41 & $0.37-0.47$ & Sub-bituminous \\
\hline & & 0.41 & $0.37-0.45$ & Sub-bituminous \\
\hline
\end{tabular}

Note: o/c - open cut 